\title{
3.2. Los modos de representación del cuerpo en la fotografía de moda. Producciones fotográficas de la Revista Catalogue
}

\section{Stefanini Zavallo, Valeria [ver currículum del autor, docente de la Facultad de Diseño y Comunicación]}

Abstract del Proyecto: Cotidianamente
el cuerpo está sometido a rituales que determinan su pose, su forma y su contenido mediante los cuales transmite sentido y comunica. En este análisis partimos de una hipótesis: lo que define a la fotografía de moda es el uso del cuerpo del modelo. El cuerpo no sólo construirá el género de la fotografía de moda sino que también construye un punto de vista acerca de la mujer. La Revista Catalogue es un corpus interesante ya que es una creación argentina que trabaja de manera original sobre el concepto de moda y belleza, con muchas producciones fotográficas por número que permiten elaborar varias problemáticas como son: la artificialidad de la pose, la relación con el dolor y la definición de cuerpo bello y cuerpo feo en la fotografía de moda contemporánea.

Palabras clave: fotografía - moda - cuerpo - fotografía de moda.

Hablar de las producciones fotográficas de la revista Catalogue nos lleva necesariamente, quizá más que en ninguna otra revista de moda, a plantearnos preguntas acerca del uso del cuerpo, la teatralización de la pose y los usos y roles que juega específicamente el cuerpo femenino en estas imágenes. A través de esta investigación buscaremos comprender el fenómeno de la fotografía de moda en su relación y tratamiento del cuerpo representado, observando cómo el vínculo que se establece entre moda y fotografía genera, elige y/ o construye los cuerpos exhibidos.

\section{Cuadernos del Centro de Estudios de Diseño y Comunicación N ${ }^{\circ} 63$}

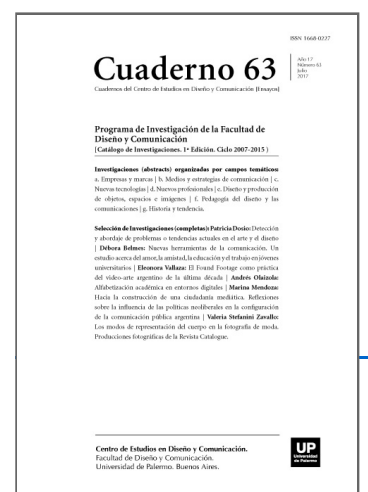

ISSN: 1668-0227

Programa de

Investigación de la

Facultad de Diseño y

Comunicación

Año XVII, Julio 2017, Buenos Aires, Argentina | 352 páginas

descargar PDF

ver índice de la publicación

Ver todos los libros de la publicación

compartir en Facebook

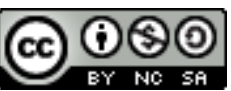

Esta obra está bajo una Licencia Creative Commons Atribución-NoComercialCompartirlgual 4.0 Internacional 
La fotografía de moda junto con la fotografía publicitaria, con la que está íntimamente relacionada, son los dos géneros más consumidos e influyentes de toda la producción fotográfica, ya que su distribución involucra sistemas que se dirigen a públicos significativamente heterogéneos y masivos. No hay nadie que en la sociedad actual pueda vivir sin estar expuesto en todo momento a las imágenes producidas por la industria publicitaria y la industria de la moda y la belleza, que saliendo de sus áreas específicas, como pueden ser las revistas especializadas en moda, atraviesan todas las miradas al ubicarse tanto en la vía pública como en el ámbito privado, en el cartel, en la vidriera, en el kiosco de diarios.

Son imágenes grandes, coloridas y muy llamativas que ocupan el espacio público y el ámbito privado, por lo que se muestran a todos y podemos verlas aunque no lo deseemos. Participar del universo visual construido por la fotografía de moda y belleza no es una opción sino una imposición que la ciudad actual nos ejerce.

La fotografía de moda por su intensidad y distribución conforma nuestra cultura visual y estética y marca parámetros de apreciación en diferentes grupos sociales y momentos históricos y éste es el motivo por el cual sostiene un interés teórico. Los modos de comunicación propios de nuestra cultura, el uso del espacio público y la ambientación de los espacios comerciales construyen una familiaridad con las imágenes propias del uso y del contacto constante y cotidiano, que dificulta en muchos casos establecer y analizar teóricamente las características que constituyen y son propias de la fotografía de moda.

Producto de esa familiaridad con los modos de producción y representación de las imá- genes todos nosotros podemos identificar cuáles son las fotografías que pertenecen, o podrían hacerlo, a una publicación de moda. Pese a esto es muy complejo establecer definiciones que permitan comprender el fenómeno y responder a la pregunta sobre qué es una fotografía de moda y cuáles son sus notas definitorias.

Uno de los primeros elementos que podemos establecer y que nos proponemos analizar es que lo distintivo de la fotografía de moda gira en torno al tratamiento que se hace del cuerpo y no así de los objetos, ropas, accesorios, peinados, cosméticos, etc. que son trabajados y exhibidos de maneras secundarias. Si bien las fotografías de moda y belleza tienen como fin último la exhibición y la posterior comercialización de productos concretos - piezas, colecciones, diseños- la fotografía de moda es independiente de la fotografía publicitaria ya que aborda su objeto de trabajo por medio de elipsis y largos recorridos que la llevan a mostrar en último término aquello que finalmente pretende ser comercializado. Las producciones fotográficas en una revista de moda funcionan como la contextualización en la que se da sentido al uso de los productos que son exhibidos en las publicidades. Para que esto funcione se ponen en juego distintas estrategias. Si el tratamiento del cuerpo humano, del cuerpo del o la modelo será aquello que distingue nuestro objeto de estudio frente a todas las otras fotografías realizadas, se hace necesaria la pregunta que moviliza esta investigación, ¿cuál es la utilización que la fotografía de moda hace del cuerpo? Y por otro lado, ¿cuáles son los modos de representación a los que se somete este cuerpo en la fotografía de moda? El corpus de imágenes que se van a investigar son las fotografías de producciones de la revista Catalogue en el período de 2007 y 2008. La Revista Catalogue aparece por primera vez en el año 2007 en Argentina, con la intención de transformarse en La biblia de la moda local y ser un referente obligado para el conocimiento y divulgación de las últimas producciones del diseño de indumentaria que se pueden encontrar y comprar en el mercado. Ante esta perspectiva la primera edición de esta revista fue considerada un evento relevante en el ámbito local y convocó a los mejores y más afamados fotógrafos, estilistas y productores nacionales para la realización de las producciones. Es ahí donde radica la riqueza de este material como corpus de investigación. La investigación del uso del cuerpo por la fotografía, por el arte o el 
diseño ha sido abordada muy profusamente por la sociología y los estudios de género, por la semiología o la psicología, y en menor medida por estudios vinculados específicamente al arte. Es por esto que la bibliografía utilizada en esta investigación hará un recorrido multidisciplinario que la enriquece.

Existen investigaciones muy interesantes que desarrollan el tema de la moda en relación a la sociología, a la semiología, a su contexto histórico, a sus aspectos técnicos y sus tipologías. Los textos de la argentina Susana Saulquin son esclarecedores para analizar el fenómeno de la moda insertado en la sociedad. Otras miradas, ya clásicas, sobre el tema, como las de Umberto Eco o Roland Barthes han permitido comprender la incidencia del vestido en el complejo desenvolvimiento social de cada uno de nosotros.

Lectura obligada para la comprensión de la sujeción del cuerpo a las miles de estrategias discursivas, su construcción, mutación, corte, recorte y violencia es el texto de Michel Foulcault, Vigilar y Castigar (2002), texto que generó un corpus por sí mismo, de estudios que se relacionan con sus planteos desde distintos lugares, o que no se relacionan en lo más mínimo y buscan establecer esa diferencia. El texto de Freud que aborda el concepto de lo ominoso o siniestro es una lectura indispensable para cualquier acercamiento a la problemática del doble, del artificio, del automatismo o del cuerpo muerto. Dentro de la sociología del cuerpo han sido muy útiles los textos de Le Breton y su abordaje del cuerpo social. El arte ha trabajado inteligentemente la relación de la moda con el cuerpo y su visibilidad a través de la fotografía: en la Argentina el trabajo de Nicola Costantino realizando objetos de consumo (como vestidos, carteras, zapatos, etc.) con piel sintética, jabones con su propia grasa extraída por medio de una liposucción, o la creación de una autómata a su propia imagen y semejanza a la que viste, pinta y engalana.

En una línea de trabajo que podemos considerar en algunos puntos muy relacionada con ésta, encontramos a Claude Cahum y Cindy Sherman, con sus mutaciones, y sus propias confecciones de sí mismas. El trabajo del artista francés Oliver Goulet que lleva mucho más allá de la sutileza de Constantino el hecho en sí de portar la carne ajena, de vestirse de un otro descarnado, con la violencia y la dureza que eso implica.

Los vestidos habitables de Fabiana Barreda que viven más allá de ser portados, en un más allá del cuerpo, algo tan complejo de pensar en un vestido, que para un diseñador no suele estar terminado hasta el momento en que rodea un cuerpo y calza, se amolda y cobra forma por esa conjunción de ser en alguien. O el trabajo de la española Yolanda Domínguez o de Vanessa Beecroft sobre el absurdo de las poses en la fotografía de moda que llevadas a la vida cotidiana ejercen una fuerte violencia en el cuerpo que las ejecuta. Otros trabajos que revisten importancia son los de grupos como el Colectiva Mujeres Públicas o Guerilla Girls, porque se centran en la violencia que ejerce la imagen publicitaria y de la fotografía de moda en el cuerpo femenino.

Todos estos artistas elaboraron desde su especificidad la problemática del cuerpo de manera lúcida y esclarecedora y desde la praxis ponen en evidencia aspectos que podemos analizar teóricamente para la comprensión de las producciones de la revista Catalogue.

Los estudios e investigaciones teóricas y los abordajes que el arte ha realizado para la comprensión y análisis de los procesos de relación e influencia que existen entre la moda y la fotografía y entre la fotografía de moda o fotografía de belleza y el cuerpo que sustenta y da sentido tanto a la pieza que exhibe como al concepto que propone el diseño, son los abordajes que se constituyen como el marco teórico con el que trabajaremos en esta investigación. Hay que destacar la importancia del rol de la elaboración de una fundamentación teórica que 
permita comprender y dar sentido a un quehacer que es eminentemente práctico. Este desarrollo es fundamental si pretendemos pasar de la capacidad técnica que nos permite realizar adecuadamente un oficio a la libertad artística que nos habilita una creación de alcance estético que trasciende los principios efímeros de la propia representación.

\section{El corpus}

Esta investigación va a trabajar con producciones fotográficas de los primeros ocho números de la revista argentina de moda Catalogue, los números aparecidos entre 2007 y 2008. La elección no es azarosa.

La Revista Catalogue hace su aparición en la escena local argentina en el año 2007, presentándose como una opción diferente en un mercado en el que abundan las posibilidades con propuestas que no se diferencian mucho las unas de las otras. Hasta el momento la revista se ha editado ininterrumpidamente con cuatro números anuales, Alto Verano, Invierno, Alto Invierno y Verano.

Catalogue busca transformarse en una propuesta totalmente distinta de las demás revistas de moda distanciándose radicalmente del concepto de revista femenina, que son el más masivo de todos los consumos de moda y tendencia. Concebida por la diseñadora Jimena Nahón, convoca desde el primer momento (y sobre todo en los primeros números) a los más importantes fotógrafos, productores de moda, estilistas, maquilladores, creativos, diseñadores, retocadores digitales, etc.

La editorial de la sexta edición es esclarecedora en cuanto a sus propósitos y objetivos: En Catalogue tomamos los conceptos establecidos y los reinventamos para brindarles otro significado desde la moda. Decidimos convertirnos en la primer guía de compras del país y conseguirlo no nos alcanzó, creamos productos exclusivos, encontramos circuitos de compras alternativos, cubrimos desfiles con otra mirada y generamos propuestas de moda como nadie más puede mostrarte. ... Catalogue, la Biblia de la moda.

La revista busca ser, como su nombre lo indica, un catálogo dirigido especialmente a la mujer que busca saber qué comprar, qué usar, dónde comprarlo y cuál es el costo de cada producto. Un objetivo claro y muy concreto que se cumple cabalmente y sin mayor dificultad. El segundo número de la revista nos propone el recorrido y modo de lectura: "Confiamos en cambiar y reorganizar la forma de observar y seleccionar, pudiendo ver antes de comprar, las más de 180 marcas nacionales e internacionales con venta en el país".

Ya desde la portada Catalogue se nos presenta como: la Biblia de la moda. Rezá por vos. Será la ayuda y socorro a la que recurre la mujer que desea verse moderna por medio del acceso y el uso de productos de diseño. Lo interesante es analizar las estrategias visuales y discursivas que se desarrollaron para que este catálogo además de ser eficiente sea atractivo de consumir y lidere una tendencia en el difícil mercado local.

El formato de la edición es pequeño $(17 \times 24 \mathrm{~cm})$ y todo sucede a página completa. El material de la revista se puede dividir en cinco grandes grupos:

1. Las publicidades.

2. Las ilustraciones. Son diseños y dibujos que sirven como portadas o separadores que pueden englobarse en un solo grupo de trabajos. En estos abundan el dibujo, el diseño gráfico y la creación libre y son secciones 
cortas de una hoja que actúan como elementos puntuales para dar color y que proponen un juego de elementos lúdicos.

3. Las largas páginas del catálogo propiamente dicho, en donde vemos cada prenda y pieza fotografiada y pequeña para que puedan entrar una al lado de la otra con un número que remite en la parte inferior a un texto que indica el nombre del local o marca y el precio al que podemos obtenerla.

4. La sección de productos propios: Catalogue Arty con prendas, accesorios y objetos creados especialmente para la revista mediante un trabajo en conjunto de diseñadores, ilustradores o artistas y las marcas. Los productos se exhiben pero no están a la venta a diferencia de los de la sección Made By Catalogue que creados con los mismos principios si se comercializan.

5. Por último, las producciones fotográficas que son nuestro tema de interés y del análisis que vamos a desarrollar.

No hay notas de color, no hay entrevistas, no hay horóscopos, dietas, consejos, recomendaciones, no vamos a encontrar nombres de personalidades, celebrities o modelos famosos, de los eventos sólo se cubren desfiles específicos y lo que se muestra son las colecciones y las pasadas y por sobre todas las cosas no hay adjetivos, el escaso texto recorre un camino que puede considerarse paralelo al de la imagen, no la explica.

Siguiendo los pasos de Roland Barthes, podríamos hacer un análisis del uso del texto en si mismo, pero dado que nuestro tema recorre otros caminos, sólo es importante señalarlo para darle una clara dimensión al peso que tendrán las imágenes (fotografías, dibujos o diseños) en el concepto general de la revista. Roland Barthes en su libro el Sistema de la moda (s.f.), analiza la moda escrita y descrita, la moda y su relación con el lenguaje articulado que crea un simulacro del objeto real que no compite con el consumo de este objeto sino que lo estimula. "No es el objeto, es el nombre lo que provoca el deseo". (pág. 13) Desde la tapa misma la gran mayoría de las revistas de moda nos comunican por medio de una tipografía llamativa textos que nos guían en la lectura de la imagen, todo está condicionado por el adjetivo, podemos encontrar pantalones divertidos, camisas llamativas, faldas atrevidas, el texto dirige la apreciación de una imagen y la ubica en su justa dimensión, que es la dimensión que la línea editorial demanda. Sexy, Hot, Caliente, Look, Guau, Chic, y muchos signos de exclamación son moneda corriente en todas las tapas de las producciones que encontramos en los kioscos. La revista Catalogue rechaza el adjetivo y todas las marcas que se utilizan para llamar la atención del lector para que la imagen se defienda y hable por sí misma.

Cada número de la revista tiene un promedio de 16 producciones fotográficas, de pocas hojas cada una (entre 2 y 8 páginas por producción en general) la mayoría de las fotos son a página completa, salvo un grupo minoritario que aparecen a doble página. No vamos a analizar todas las producciones sino algunos temas que vinculan a varias de distintos fotógrafos. Si observamos el uso del cuerpo en la fotografía de las producciones de la revista Catalogue lo primero que nos llama la atención es una coherente y sistemática utilización de la pose. La pose se nos presenta como la teatralización de la feminidad, como una puesta en escena en la que el elemento que más sobresale es la rigidez al congelar el movimiento que deja en evidencia la artificialidad de todo el mundo que es recreado por la producción fotográfica. La rigidez de la pose nos remite a algunos temas que van a ser el centro de nuestro análisis. En primer lugar remite al cuerpo muerto, la pose como rigidez es la ausencia del movimiento, de la energía propia del cuerpo vital. Se relaciona con esto el cuerpo artificial, la pose es lo opuesto 
a la naturalidad y la exacerbación de esa pose nos lleva al cuerpo autó- mata, al cuerpo creado de manera artificial.

En segundo lugar la rigidez de la pose nos remite a un cuerpo doloroso, sometido y doliente, al cuerpo sometido por la moda, por la foto, por el tiempo congelado. Por último analizaremos la creación y utilización de un cuerpo bello que acentúa la dicotomía con el cuerpo feo, y el trabajo fotográfico en función de reproducir cierto tipo de estereotipos vinculados con el cuerpo femenino y sus roles sociales. Estos tres ejes son los que abordaremos en este análisis.

La pose y el artificio

Al hablar de pose en fotografía o en cualquier manifestación artística incluimos en nuestro campo de estudio al cuerpo con todo lo que éste pone teóricamente en juego. El cuerpo es aquél que porta el sentido tanto de la pose, del gesto y de la moda. Le Breton contempla al cuerpo dotado de un sentido social y cultural mucho más allá de sus características propiamente biológicas y que construye sentido continuamente.

El cuerpo, moldeado por el contexto social y cultural en el que se sumerge el actor, es ese vector semántico por medio del cual se construye la evidencia de la relación con el mundo: actividades perceptivas, pero también la expresión de los sentimientos, las convenciones de los ritos de interacción, gestuales, expresivos, la puesta en escena de la apariencia, los juegos sutiles de la seducción, las técnicas corporales, el entrenamiento físico, la relación con el sufrimiento y el dolor, etc. (2011, p. 7) La pose es artificio y lo contrario a ésta es lo natural, la naturalidad que pueda percibirse en la fotografía o imagen instantánea. La pose por sobre todas las cosas siempre involucra a otro que mira y/o registra. Si posamos solos es la mera práctica para estar listos al momento de ser mirados, porque es para eso que posamos, para llamar la atención sobre nosotros, sobre nuestro cuerpo o las prendas que este porta. La pose es parte del rol social, tanto el hombre como el animal posan para agradar, para aparearse, para inspirar temor o para ser representados. La pose es parte del rito social. Si tenemos en cuenta estos tres aspectos: el artificio, la mirada del otro y/o el registro, podemos comprender rápidamente la importancia de la pose en la fotografía en general y por sobre todo en la fotografía de moda.

En sus primeros años los modos del registro fotográfico obligaban a la pose por sus características técnicas. La lentitud de los tiempos de exposición forzaba al modelo a permanecer estático durante largos periodos para que su imagen logre la imprimación en la película. Para ayudar a sostener la pose se llegaron a diseñar instrumentos de apoyo para la cabeza y que alivianaban el peso de la espalda, tal era la dificultad de obligar al cuerpo a permanecer quieto.

Los retratos que nos muestra la primera fotografía son de largas sesiones de pose estática y paciente. Este requerimiento técnico propio de la fotografía emparentaba el resultado obtenido por la cámara con el de la pintura lo que era satisfactorio para el comitente o cliente. La fotografía de retratos viene a reemplazar y a masificar uno de los géneros más extendidos del arte, y sobre todo en los primeros momentos busca presentar al modelo de formas muy equivalentes. El modelo sentado, representado de medio cuerpo o cuerpo entero, con sus mejores vestidos y los atributos que establecen y señalan su pertenencia de clase, el juego de luces y sombras que enfatizan los rostros y las manos, el rostro ubicado de manera frontal o tres cuartos de perfil y por sobre todas las cosas la pose, la preparación de la imagen que perdurará en el tiempo mediante el uso de escenografías, gestos y vestuario. La pose fotográfica es heredera de la pose pictórica. 
En su texto sobre la fotografía Roland Barthes piensa brevemente sobre la importancia de la pose, qué lugar ocupa y qué relaciones establece entre el modelo y el fotógrafo.

...lo que fundamenta la naturaleza de la Fotografía es la pose. Importa poco la duración física de dicha pose incluso si el tiempo ha sido de una millonésima de segundo, ha habido siempre pose, pues la pose no es, no constituye aquí una actitud del blanco, como tampoco es una técnica del Operador, sino el término de una" intención" de lectura. (1989, p. 122-123) Barthes distingue luego la imagen captada por la foto de la imagen captada por el cine, la diferencia radica en la captación de ese instante que quedará congelado y que no da cuenta del movimiento, de la vida propia del cuerpo, de su respiración, de sus gestos y sus latidos. La cámara fotográfica detiene y condensa una unidad mínima en la que la realidad adquiere nuevos sentidos.

El fotógrafo de moda no trabaja con la imagen instantánea, busca la pose sofisticada y artificiosa que sólo el cuerpo entrenado de una modelo puede realizar y las huellas de esa acción premeditada quedan en evidencia. Una producción de modas es un plan diseñado previamente, ensayado y calculado, nunca es arbitrario. Como explica Roland Barthes: ... al mirar una foto incluyo fatalmente en mi mirada el pensamiento de aquel instante, por breve que fuese, en que una cosa real se encontró ante el ojo. Imputo la inmovilidad de la foto presente a la toma pasada, y esta detención es lo que constituye la pose. (1989, p. 123) El hecho mismo de la pose implica saber que algo estuvo y se detuvo al saberse registrado y por consiguiente mirado. El hecho de posar implica la conciencia de que el fotógrafo mira y que la foto que se produce también será vista. El sujeto es consciente de ser doblemente mirado, en esas dos instancias que son diferentes.

No es nuevo el interés que despiertan las complejas posiciones en las que se mueven y se exhiben los cuerpos de las modelos y que quedan registradas por las fotografías de moda y la fotografía publicitaria. Muchos estudios de género han abordado el problema analizando la pose forzada como un lugar de sometimiento de la mujer y por sobre todas las cosas relacionando esta pose con lo impuesto y con el dolor que se le inflige al cuerpo femenino para agradar y para ser catalogado como bello, deseado y cuidado.

Es lo que Le Breton denomina como las "inscripciones corporales" aquellas marcas a las que sometemos al cuerpo para pertenecer a un grupo, para ser reconocidos de determinada manera y para distinguirnos de otros grupos, "la marca social y cultural del cuerpo puede llevarse a cabo a través de una escritura directa de lo colectivo sobre la carne del actor. Puede hacerse como un recorte, una deformación o un agregado". (2011, p. 62) Al cuerpo femenino se le propone el adorno artificial para ser aceptado por sí misma y por su entorno, un adorno que es un color de piel especialmente logrado por medio de productos o sesiones de aparatología diversa, un olor siempre diferente al propio, una forma física estereotipada, una pose marcada por lo artificial, un cuerpo vestido, adornado y preparado.

Pero al cuerpo femenino además del adorno se le exige una presentación. Tradicionalmente la feminidad se pone en juego en el modo en que el cuerpo se presenta en sociedad. La mujer crece sabiendo que hay un modo se sentarse, de cruzarse de piernas, de pararse y de andar, que hay gestos permitidos, tonos de voz, proximidades apropiadas y que eso construye su belleza física y su dimensión moral. La foto de moda nos llama la atención sobre ese gesto o esa pose por medio de diferentes recursos. En primer lugar exacerba la pose tradicionalmente aprendida por la mujer y la congela en el tiempo y en segundo lugar coloca al cuerpo femenino en una pose que culturalmente se le asigna al hombre, en los dos casos lo que esto produce es extrañamiento y enfoca nuestra atención en el cuerpo que la sostiene. 
La artista española Yolanda Domínguez elabora un cuestionamiento del uso de los cuerpos de las modelos en las producciones de fotografías de moda con una lúcida acción urbana en la que instala en la vía pública a mujeres vestidas y arregladas cotidianamente, mujeres comunes que se presentan en las mismas poses en las que podemos encontrar a las modelos en cualquier revista de moda. (Anexo №1) Fuera del contexto de la revista las poses generan imágenes alarmantes, que vinculan esos cuerpos al sufrimiento, al accidente, hacen que el caminante desprevenido les ofrezca su ayuda o directamente llame por socorro para esas mujeres agónicas.

El trabajo de Yolanda Domínguez visibiliza el problema. El cuerpo y el uso que se le da a éste en el marco de una revista de moda deja de ser elegante, glamoroso o sensual ni bien sale de las hojas de papel o ni bien esa pose migra a otros cuerpos que no cuadran con el estereotipo del cuerpo de la modelo.

Desde otro lugar la artista italiana Vanessa Beecroft aborda la problemática de la pose y del cuerpo también desde la acción artística. Ella trabaja con grupos compuestos por varias mujeres que se ubican casi o totalmente desnudas en distintos tipos de espacios como pueden ser museos, galerías, ferias de arte, instituciones, en la calle, etc.

En todas las intervenciones las mujeres elegidas son jóvenes, bellas, altas y muy delgadas, y todas mantienen las exigencias corporales de una modelo profesional. (Ver Anexo $\mathrm{N}^{\circ}$ 2) Las poses imitan a las que podemos observar en producciones fotográficas de moda o publicidad y a las que vemos en una pasarela. Las modelos siempre llevan zapatos con un alto taco aguja, en algunos casos como única prenda. Si están vestidas llevan trajes de baño o ropa interior, medias o siempre alguna prenda ceñida al cuerpo y suelen estar todas las mujeres vestidas iguales, salvo en los casos en los que una de todas ellas aparece desnuda en contraposición a las demás que se encuentran levemente vestidas.

La artista las ubica con la consigna de estar quietas, erguidas y bellas pero a medida que el tiempo pasa, vemos como los cuerpos se cansan y las poses se desarman, las modelos necesitan moverse y luego de un tiempo no resisten estar paradas con los altos tacos y se sientan, los cuerpos cansados procuran seguir siendo bellos y vemos como hasta en el último momento las modelos tratan de improvisar una nueva pose que no las mortifique. En este caso la pose es realizada por un cuerpo similar al que podríamos encontrar en cualquier revista de moda, lo que no es equivalente es la duración y la exigencia a la que se somete al cuerpo. La pose que queda detenida en la imagen fotográfica duró solo un segundo en la modelo, ver el deterioro de esa pose es casi igual a ver el deterioro del cuerpo o a poner de manifiesto la artificialidad de la situación.

El resultado final termina siendo equivalente en las dos artistas, las acciones ponen de manifiesto la artificialidad y la violencia de la pose que en el ámbito de las revistas de moda o en las publicidades vemos como belleza.

La pose es artificio.

La revista de moda, como una novela literaria, conforma su propio verosímil y dota de sentido a un grupo de elementos que de otra forma o que por separado no podrían tenerlo. El caso de la revista Catalogue reviste su peculiaridad ya que las producciones fotográficas llevan al extremo la idea de desvincular la foto de moda con la foto publicitaria. Nada en las imágenes busca inducir la compra de productos, sino que buscan establecer con 
claridad el público al que se están dirigiendo, buscan generar el contexto en el que esos productos serán usados y tendrán sentido.

Por su propia característica de ser catálogo de moda, la revista encuentra que puede diferenciar muy claramente las secciones que orientan al lector al consumo de productos y las que conforman apartados enfocados en la riqueza visual y conceptual.

El texto que aparece en la edición número ocho explica la sección de Catalogue Arty de ese número, pero puede servir como texto para comentar las elecciones de las producciones fotográficas.

Desafiar lo impuesto, lo aceptado, poniéndolo a prueba con nuestra imaginación nos lleva a generar los productos Catalogue Arty. Estos artículos, creados junto a artistas, diseñadores e ilustradores son únicos y no están a la venta. Su objeto es transmitir un concepto a través del arte. El dinero no vale! La estrategia de diferenciación es clara, hay productos para vender y otros para admirar y cada uno tendrá un trabajo y un enfoque fotográfico propio.

En el catálogo las prendas procuran ser neutras y se presentan planas una al lado de la otra sin destacados ni jerarquías, en las producciones fotográficas las prendas cobran un sentido muy diferente, en algunos casos desaparecen, o se rompen, o mutan, a veces se mezclan con otras prendas, se usan de formas inapropiadas (como una falda que se coloca de sombrero o manto), se mezclan con prendas antiguas, prestadas o alquiladas que serán imposibles de comprar.

La foto de moda utiliza distintas estrategias para dar sentido a las imágenes. Estrategias que elaboran el uso del cuerpo y del espacio en el que este habita dentro de la foto. En primer lugar, como ya dijimos anteriormente, el uso del cuerpo, la pose y la gesticulación que permiten la lectura de la ropa pero sobre todo del estilo. La creación de cada prenda se completa al ser portada, al llenarse de un cuerpo y cobra un sentido por la forma en que ese cuerpo la muestra y se mueve dentro de esta.

Andrea Saltzman realiza una investigación que aborda la relación del cuerpo con el diseño de indumentaria y plantea que, "dado que la ropa no es 'autoportante', sino que toma forma a partir de un cuerpo - usuario, cuerpo y vestimenta establecen una relación que hace que ambos modifiquen su estatus constantemente". (2009, p. 10) En la revista Catalogue las hojas del catálogo nos muestran las prendas claramente en plano enfocadas desde un punto de vista alto y las producciones fotográficas apuntan a la riqueza visual más allá de si muestran con claridad o no alguna prenda o ninguna o si justo la que muestran es imposible de adquirir. Hay una ruptura entre la prenda y el cuerpo y en consecuencia la creación de sentido se trabaja por separado. La ropa se vende sin cuerpo y el cuerpo genera un sentido más allá de la ropa. Esto que funciona integrado en todas las revistas de moda al separarse arma lecturas complejas y en muchos casos confusas.

Una producción fotográfica de una revista como la Vogue elabora el contexto de utilización de una prenda, esto genera un sentido para la prenda y un sentido para la revista. La revista Vogue ha construido durante años la posibilidad de que todos la reconozcamos como la revista de moda que marca la tendencia internacional. Si una prenda aparece en la revista sabemos que esa prenda será usada en la temporada, el modo en que aparece en la producción fotográfica inducirá el modo en que será usada por el público. 
La artista plástica argentina Fabiana Barreda trabajó en su serie Vestidos Habitados fotografías de prendas planas colgadas de perchas, si nos muestra un cuerpo es una foto que aparece adentro o arriba de ese vestido que siempre es plano. El vestido se arruga y pierde sentido al no estar lleno de alguien, el vestido es vestido en cuanto viste, fue pensado para un cuerpo y para ser usado. En la percha, recortado contra un fondo blanco, el vestido es tristeza y abandono.

En segundo lugar encontramos la escenografía de esa producción fotográfica. La ambientación de la foto es la creación de un mundo diseñado como marco para que ese cuerpo exista, tal como lo plantea Roland Barthes, En la fotografía de moda el mundo es de ordinario fotografiado como un decorado, un fondo y una escena, en suma, como un teatro. El teatro de la Moda es siempre temático... En este decorado significante parece vivir una mujer; la portadora del vestido. (s.f., pp. 258-259) La teatralización del espacio es usada con mayor o menor maestría en distintas revistas y por diferentes fotógrafos. Pensemos solamente en los mundos mágicos recreados por la revista Vogue en algunas producciones y como se comienza a estandarizar el concepto en muchas fotografías de moda, el uso de la asociación fácil que vincula la moda urbana con la escenografía de la fábrica o de la construcción, la primavera con el campo y las flores, lo acogedor con el interior de una cabaña, el plateado con la vida nocturna y urbana o con el futuro, etc. Nuevamente el decorado nos hablará de la prenda y generará un sentido alrededor de esta y también nos hablará de la revista, de su riqueza visual y sus posibilidades materiales.

Es interesante ver que las producciones de Catalogue colocan a los cuerpos en fondos neutros, no hay decorado, no hay fondos, no hay escenografía. Por tomar un ejemplo en la revista número 2 de las once producciones sólo 4 trascurren en lugares que pueden ser reconocibles o tienen elementos que identificamos, la segunda producción Warrior in love, sitúa a la modelo en unas escaleras de cemento, o la producción número 4, Balcón terraza, nos presenta elementos que se pueden asociar con el tema del esparcimiento y las vacaciones, como son una reposera, sombrilla, juegos de playa, etc.

Todo lo demás es neutro, son fotos de estudio, con el cuerpo en primer plano como único elemento portador de sentido. Es por esto que el cuerpo es el elemento constitutivo de la foto, lo único necesario. Y el cuerpo está presentado en la pose.

El cuerpo en su sentido ominoso. Sórdida. La quietud de lo siniestro.

Si bien ya establecimos que toda pose implica una rigidez en la que el cuerpo se congela de manera artificial, hay poses que exacerban esta característica estática transformándola en un estilo con contenido. En la exacerbación de la pose es donde podemos leer distintos significados e intenciones.

La producción Sórdida del número 6 de la colección Alto Verano de 2008, es una idea de Jimena Nahón, Diego Speroni y Sol Abadi, con fotografía de Sol Abadi y retoque digital de Diego Speroni. Son cuatro fotografías a página completa en las que la modelo se transforma en una muñeca por medio de la rigidez de la pose y del retoque digital que transformó la textura de su piel en la de un ser artificial de porcelana. (Ver Anexo No 3) La primera de estas imágenes de mujer perfecta y fantástica viste de blanco como una novia y la última de negro como una viuda, momentos de la vida antagónicos en los que la modelo petrificada no puede mutar su expresión, instancias en las que ha quedado congelada en una indiferencia distante. Todas las mujeres llevan guantes y vestidos lujosos. Las otras dos fotografías nos muestran a la misma modelo, una con vestido rosa 
bordado en dorado con flores y pajaritos en las manos y la otra viste una lujosa capa de piel azul en el mismo tono de las flores que sujeta. La joven viuda en lugar de flores lleva un delicado marco dorado con una estampita del corazón de Jesús. Las cuatro llevan el cabello recogido y delicados sombreros o tocados.

Esta producción construye el modelo de una feminidad delicada y sutil, una feminidad de adorno tan contenida en si misma que se representa por medio de la figura de una muñeca de porcelana, frágil y delicada, incapaz de moverse o accionar dinámicamente.

Esta conformación de mujer sutil contrasta con el nombre de la producción, "Sórdida" que nos remite a algo impuro, indecente, inmoral. ¿Dónde está la mancha de esta mujer que a primera vista es perfecta y pura? La relación entre la mujer y la muñeca fue trabajada magistralmente en el texto de E. T. A. Hoffmann, El hombre de arena, donde el estudiante Nathaniel alejado de su casa y de su familia conoce a la hija de su maestro, Olimpia y se enamora perdidamente de ella sin notar lo que era evidente para todos, que ella en su perfección no era más que una muñeca. A los ojos de él ella se transforma en el perfecto femenino, no habla, no diciente, no opina, sus modales son impecables, canta afinadamente y su rostro y cuerpo son perfectamente bellos sin mácula o imperfección alguna. El final se avecina y nada puede terminar bien, la constatación del engaño enloquece al joven Nathaniel quien pierde la cabeza. Este es el texto que da origen a la indagación que realiza Sigmund Freud sobre lo ominoso o siniestro. El texto inicia con la pregunta acerca de qué es lo ominoso y si es que hay algo que pueda definirse como tal plantea lo siguiente, No hay duda de que pertenece al orden de lo terrorífico, de lo que excita angustia y horror; y es igualmente cierto que no siempre esta palabra se usa en un sentido que se pueda definir de manera tajante. Pero es lícito esperar que una palabra-concepto particular contenga un núcleo que justifique su empleo. Uno querría conocer ese núcleo, que acaso permita diferenciar algo "ominoso" dentro de lo angustioso. (2009, p. 219) Freud no es el primero en analizar el texto de Hoffmann en su relación con lo siniestro, el mismo recupera el texto que E. Jentsch en 1909 escribe sobre este cuento donde atribuye la sensación de lo siniestro a la aparición de la muñeca Olimpia reemplazando a una joven real, "E. Jentsch destacó como caso notable la duda sobre si en verdad es animado un ser en apariencia vivo, y, a la inversa, si no puede tener alma cierta cosa inerte". (2009, pp. 226-227) A Freud esto no le alcanza pero si le sirve para empezar, como disparador del análisis. Cita el cuento de Hoffmann pero ve que la presencia de la muñeca no es lo único ni lo mayormente ominoso, en el centro del relato ve a la figura del "Hombre de arena" que arranca los ojos a los niños, una historia contada en el principio del cuento cuando un Nathaniel niño espía la reunión de su padre con el abogado Coppelius y es descubierto por ellos, el viejo lo amenaza con echarle carbones calientes en los ojos para sacárselos. Un año más tarde después de una visita del abogado el padre muere en medio de una explosión y Coppelius desaparece. Tiempo después Nathaniel lo reencuentra pero este lleva otro nombre, Giuseppe Coppola, quien vende barómetros y "también bellos ojos" o sea binoculares, y por medio de uno de estos aparatos será como el joven descubrirá que en la casa de enfrente vive Olimpia "bella pero enigmáticamente silenciosa e inmóvil... Pero Olimpia es una autómata al que Spalanzani le ha puesto el mecanismo de relojería y Coppola -el Hombre de la Arena- los ojos" (2009, p. 229) nos cuenta Freud para incluir el problema de la perdida de la vista y de la falsedad del ojo de Olimpia dentro del análisis sobre lo ominoso.

Freud plantea que lo verdaderamente terrorífico es la amenaza de la pérdida de los ojos y no solo la incertidumbre intelectual que genera la confusión acerca de la destinataria del afecto. Lo siniestro lo genera la angustia por la pérdida de los ojos que se relaciona con el complejo de castración. Hacía el final del relato Olimpia perderá sus ojos provocando la constatación de su construcción y por consiguiente de su artificialidad, 
Coppelius o Coppola se los arrancan dejándola tirada e inerte en el suelo. En contraposición, los ojos será lo único que la muñeca de Catalogue va mantener. Todo su cuerpo ha sufrido un retoque digital que modifica su textura, que lo sustituye por el de una muñeca de porcelana pero los ojos serán lo único real y humano, con el brillo y la profundidad que les son propios a los ojos reales.

El uso del cuerpo crea sentido. En este caso la pose que lo moviliza o lo detiene y la ayuda del retoque digital conforman una imagen de mujer. Esta construcción femenina distante y perfecta es siniestra porque es mentira, por que abusa de la credulidad del enamorado que cae víctima de la trampa sin tener fuerzas para resistir. En el cuento este engaño es una estafa que daña y mata y que afecta a toda la ciudad ya que Hoffmann nos cuenta que a partir de ese momento todos buscaron constatar cuál era la materia de la que estaba hecho su amor, cuán humanas eran todas las chicas de las que los jóvenes de la ciudad estaban enamorados Para convencerse enteramente de que no amaban a ninguna muñeca de madera, muchos amantes exigían a la amada que no bailase ni cantase al compás, y que se detuviese al leer, que tejiera, que jugase con el perrito, etc., y sobre todo que no se limitase a oír, sino que también hablase y que en su hablar se evidencie el pensamiento y la sensibilidad. (1993, p. 86) El defecto es la comprobación de la vida, la perfección es lo irreal y por consiguiente implica un engaño y atentado nocivo para la vida misma. Este uso del cuerpo transformándolo en un objeto no es exclusivo de esta producción sino que se repite sistemáticamente en distintas producciones y apartados de la revista Catalogue. La revista genera productos en asociación con distintas marcas tal es el caso de una línea de maquillaje que se diseño alrededor del tema de la muñeca Barbie. La edición de Catalogue número 3 de 2007, nos muestra una foto a página completa en la que dos bellas modelos (una rubia y otra morocha) se igualan llamativamente a la muñeca desde el gesto de sus caras con la mirada perdida y la boca entreabierta hasta el retoque digital que transforma la textura de su piel en plástico y la de su cabello en hilos de nylon brillantes. La imagen remata con la siguiente frase que es más que expresiva: "Barbie. A la moda, siempre cambiante, un icono. En todo sentido un ídolo. Esta primavera, la muñeca Barbie está influida por M.A.C. Barbie loves M.A.C. es una edición limitada de productos creados para todas ustedes, muñecas vivientes". (2007, p. 60) Lo único que en las dos modelos no está intervenido son nuevamente los ojos que mantienen el brillo húmedo de los ojos de seres reales a los que son ajenos los muñecos o autómatas. Separadores en distintos números de la revista recurren directamente al uso de fotografías de muñecas o maniquíes ya sea completos o en pedazos fragmentados para reemplazar a modelos reales o sus partes.

En su texto Freud analiza la relación entre la recepción de la autómata Olimpia como imagen y símbolo de lo siniestro y los juegos infantiles, la autómata es la muñeca con la que las niñas juegan y no entra en el territorio de lo reprimido, sino que se abandona en el paso del la niñez a la vida adulta. Pero desde todo punto de vista no es el objeto con el que el niño varón acostumbra jugar. Lo doloroso del cuento de Hoffmann reside en que es Nathaniel quien se relaciona con Olimpia, sería el tipo de vínculo y no el objeto en si lo que penetra la categoría de lo ominoso. En el caso de las producciones de la revista el carácter siniestro reviste el reemplazo que se establece del cuerpo femenino por el cuerpo objeto y la trasformación de las receptoras / lectoras de la revista en bienes de consumo en el mismo nivel que cualquier otro producto del catálogo, el remate de la frase de la producción de Barbie “...para todas ustedes, muñecas vivientes” ilustra el lugar que ocupa la lectora que es igualado al de un objeto.

Simone de Beauvoir inicia su libro con una frase inolvidable, No se nace mujer: llega una a serlo. Ningún destino biológico, físico o económico define la figura que reviste en el seno de la sociedad la hembra humana; la civilización en conjunto es quien elabora ese producto intermedio entre el macho y el castrado al que se califica 
como femenino. Sólo la mediación de un ajeno puede constituir a un individuo en Otro. $(1987$, p. 13) El ser femenino es la construcción que todos en conjunto abonamos cotidianamente con diversos sentidos y valores, como dice Margarita Iglesias Saldaña "el significado cultural es determinante en la construcción de la feminidad y de lo femenino" (2007). El aporte de Beauvoir a los estudios de género fue la concepción de un ser mujer que no está dado por su propia naturaleza biológica sino que se modela socialmente. Es por esto que es importante el análisis de la repetición sistemática de un formato de mujer y del tratamiento del cuerpo femenino en las revistas de moda y en las publicidades.

Papier Colle. El monstruo en lo siniestro

Esta producción aparece en la revista número 5 del año 2008 para la colección Verano. La fotografía es de Eleonora Margiotta y la producción de Suzuki Díaz y consta de 11 fotografías en las que se elaboran el tratamiento del cuerpo como un objeto o su cosificación asimilándolo a una muñeca o maniquí y por sobre todo trabaja el concepto del doble. (Ver Anexo $N^{\circ} 4$ ) La objetivación de estos cuerpos concretos es más sutil que en la producción anterior, el retoque digital no transforma la materia de las modelos, el juego no es el simulacro. El recurso que se utiliza es el maquillaje, la pose, el gesto por medio de los cuales la modelo parece una muñeca pero no se transforma en una.

Cuatro de estas fotografías son de dos modelos calvas con pelucas rubias mal colocadas que ponen en evidencia que son cabello artificial por la calidad y por el brillo de las hebras de nylon. Por medio del vestuario, el maquillaje y la pose las dos modelos simulan ser iguales, aunque mirando con atención vemos que no lo son. En otras tres fotografías aparece solo una de las dos modelos (imposible precisar cuál de ellas) con poses en las que se enfatiza su calvicie lo que asimila su rostro al de un maniquí y mueve y acomoda sus manos y su cuerpo de manera mecánica y rígida para que la relación con la muñeca sea total. Así como Freud analiza el engaño de la autómata para comprender la matriz de lo siniestro también lo va a relacionar con otros temas como la aparición del doble, "la aparición de personas que por su idéntico aspecto deben considerarse idénticas". (2009, p. 234) Idénticos físicamente o idénticos en el pensamiento como en la telepatía, el retorno de lo igual, la repetición, lo que vuelve a suceder una y otra vez es lo que nos impone la idea de lo fatal y la sensación de algo que no podrá evitarse y es eso lo que Freud interpreta que nos remite a lo siniestro.

La artista Nicola Costantino trabajó el tema de la creación de un doble en su obra Trailer que es una instalación concebida para la Fundación YPF, en donde se distribuyeron casas rodantes (trailers) en el inmenso espacio de la Fundación, y carteles imitando los que anuncian estrenos de películas en un cine y se presentó el tráiler cinematográfico de 3.17 minutos de duración de una película inexistente.

Trailer es el avance que nos cuenta un momento particular en la vida de la artista, que comienza cuando Costantino comprueba que está embarazada y comparte con todos nosotros el resultado de un análisis casero y para responder a los requerimientos que este momento tan significativo representa en la vida de una mujer y poder afrontar el trabajo que implica, decide crearse una compañera con quien compartir el proceso. Toma moldes de su cuerpo para construir otra versión de sí misma, vacía los moldes y pule las piezas que van fraguando, las arma y organiza, pinta la piel, los ojos, las uñas, coloca las pestañas una a una, cose su ropa igual a la propia. 
El video nos permite ver como la doble y la panza de la artista crecen en paralelo. Una vez que la doble está terminada es el momento en el que nace el bebe y ambas lo cuidan, lo miran con amor, y lo acompañan. El final se anuncia en los gestos de desagrado que la artista explicita cansada de la mirada de la otra, hecha a su imagen y semejanza pero en la que la ausencia de vida genera una expresión extraña y distante, carente de inteligencia. El final se anuncia en un título que se recorta en letras rojas sobre un fondo negro para plantear que "El doble es lo ominoso", y las imágenes que lo captan lo devuelven siniestro. El doble es lo ominoso y la artista pone en evidencia el peso de la mirada del otro (o la propia) que constantemente esta a nuestra espalda. El otro texto que aparece hacia el final del video nos habla de "Lo inevitable". En el final, la destrucción del doble es imposible de evitar.

La muñeca construida es doblemente siniestra, por ser doble y por pretender ser un ser vivo. Por la copia y por el engaño. En fotografía el tema del doble nos remite inmediatamente a la obra de Diana Arbus o a la de artistas como Loretta Lux, en ambos casos el resultado es igualmente perturbador. El espectador siente un error en esas imágenes que nos muestran la duplicidad de un individuo, que justamente por ser tal lo pensamos como único e irrepetible. La confirmación de que hay dos o tres iguales a uno mismo es perturbadora.

Ambas fotógrafas utilizan iguales recursos para enfatizar el parecido, visten a los modelos con la misma ropa, el mismo peinado y por sobre todas las cosas la misma pose, el mismo uso del cuerpo que produce la sensación de un truco o efecto digital. Diane Arbus no solo realizó series sobre gemelos o trillizas sino sobre otros personajes con características físicas diferentes a las de la media, como personas más altas o más bajas, enanos, jorobados, personas que trabajaban en circos o ferias itinerantes y que por su aspecto o por su ocupación eran lo que ella misma llamó Freaks.

Este término se generalizó a partir del título de la película de Tod Browning de 1932 en la que el director trabajó con personajes de circo, seres mutilados, mujeres siamesas, enanos, y distintas personas cuyas características físicas los separan del resto.

El vínculo de Diane Arbus con sus modelos es objeto de muchos análisis e interpretaciones. Susan Sontag, con quien compartió muchos estudios y diferentes momentos no puede dejar de mencionar que la mirada de Arbus representa el punto de vista de una joven judía de clase media de la ciudad de Nueva York acerca de "el otro". Y la construcción de la diferencia no deja de ser la mirada de una joven acomodada que se dedicaba junto con su marido a la fotografía de moda y que de repente descubre un mundo que la fascina porque es distinto, sus propias palabras nos ilustran un acercamiento a esa mentalidad que busca lo exótico y se sorprende y maravilla frente a las diferencias: Freaks ha sido lo que más he fotografiado. Fue una de las primeras cosas que fotografié y ha sido terriblemente motivador para mí. Simplemente, solía adorarlos. Aún adoro a algunos de ellos. Con esto no quiero decir que sean mis mejores amigos, ellos me han hecho sentir una mezcla de vergüenza, temor y asombro. Existe una especie de leyenda acerca de los/as freaks. Como esa persona que en un cuento de hadas te detiene y te exige que resuelvas un acertijo. La mayoría de la gente se pasa su vida temiendo pasar por una experiencia traumática. Los Freaks nacieron con sus traumas. Ellos ya han pasado su prueba. Son aristócratas.

No se escapa la relación paternalista de la artista con sus modelos. Ella "los adora", han sido su material de trabajo y reflexión durante años y no por eso deja de mencionar la sensación de vergüenza que una joven y bella burguesa siente frente a su cercanía, no son sus amigos pero no puede evitar la atracción que le producen. Es siniestro lo que nos atrae, si nos resulta indiferente o instantáneamente repulsivo ya no sería ominoso. Para 
que lo sea es necesaria la fascinación que Nathaniel siente por Olimpia, la que Diana Arbus siente por "sus freaks", la que leemos en la repetición de las producciones de la revista Catalogue utilizando sistemáticamente modelos que remiten a la muñeca inerte, mujeres duplicadas, mutiladas o dolientes.

La producción Caperucita Roja con fotos de Nora Lezano, aparece en la revista Catalogue $N^{\circ} 6$ del 2008 para la colección Alto Verano. Son cinco fotos con fondo blanco sobre los que se recortan uno a uno los personajes del cuento infantil. En la primera foto una niña con malla roja y caperuza nos remite a la protagonista, en la segunda una señora mayor con delantal de cocina sobre una malla personifica a la madre, luego es el turno del lobo (también en malla), la abuela en malla y por último el leñador esta vez en bermudas. (Ver Anexo $\mathrm{N}^{\circ} 5$ ) Todos los modelos son de la agencia Freak Models que en su página se define a sí misma como: "Somos una agencia que busca trascender los convencionalismos estéticos, desarrollando y valorando una visión particular de la belleza sin límites de edades o razas. La originalidad en la belleza, en distintas intensidades y formas: Hard and Light".

La agencia trabaja con modelos que no responden al concepto publicitario de belleza y podemos encontrar en su catálogo: personas de un aspecto totalmente cotidiano que solo nos llaman la atención por estar en el catálogo de una agencia de modelos hasta personas muy gordas o muy delgadas, enanos, travestis, gente tatuadas o con cantidad de aros y gemelos. El concepto Freak de la revista Catalogue es una mirada edulcorada de la búsqueda extrema de Diane Arbus. Los modelos elegidos solo llaman nuestra atención por estar en una revista de moda, lugar en el que concebimos encontrar otros cuerpos y otro tipo de belleza pero no por algo que los defina en particular. La pose tiene sentido y belleza solo dentro del contexto de la revista, como ya nos mostró Yolanda Domínguez, cuando la pose se replica en otros ámbitos y en otros cuerpos es un chiste o un accidente. Lo mismo observamos cuando la revista se acerca a trabajar con otros estereotipos físicos, representan su propio verosímil, dentro de la revista son Freaks en la calle son personas perfectamente normales y cotidianas.

La elección de modelos que no se circunscriben al estereotipo trabajado por las revistas de moda y belleza es algo utilizado por muchas producciones de diferentes revistas. Quizá uno de los ejemplos más significativos de los últimos años fue la producción Pussy West del polémico número 913 de la Revista Vogue de 2011, con fotografías de Tom Ford y realización de Benjamín Bruno. (Ver Anexo № 6) Esta edición de la revista fue polémica por otra producción: Cadeaux con fotografía de Sharif Hamza y realización de Mélanie Huynh, en la que niñas pequeñas vestían y posaban como sensuales mujeres adultas, decisión que le costó el puesto de editor al fotógrafo Tom Ford.

La producción Pussy West si bien no es polémica en la misma dimensión que lo es erotizar a niñas pequeñas, es interesante y llamativa de analizar ya que muestra a una pareja mayor de 70 años besándose y tocándose de manera muy sensual y con una connotación erótica y agresiva. El fotógrafo se centra en enfocar los pechos desnudos, el cuello o las piernas de una mujer mayor que es algo que las revistas de moda y belleza nos han vedado, vemos arrugas y piel sin tonificar, manchas en las manos de dos personas que más allá de la edad siguen siendo hermosas y sensuales.

La pareja es bella y glamorosa, viste lujosamente a la moda, pero son mayores y eso que en el mundo es algo totalmente normal en el interior de una revista no, y en este caso la simple edad de los modelos transforma a la producción fotográfica en algo diferente, llamativo y revolucionario. La belleza, la sensualidad, el erotismo y el 
sexo en los adultos mayores parece transformarlos en seres tan extraños como los que veía Diane Arbus en sus recorridos por las ferias.

Madura inocencia. La muerte y lo siniestro

El Número 4 de la Revista Catalogue aparecido en el Alto Invierno de 2007 tiene dos producciones con niños, lo que es inusual dentro de la revista. La primer producción se titula Madura Inocencia y está conformada por siete fotos de Nora Lezano y Sebastián Arpesella. (Ver Anexo No 7) Los niños se recortan contra un fondo oscuro de un espacio de fábrica o depósito que parece estar abandonado y visten prendas antiguas que un epígrafe define como capitas de terciopelo, vestidos de convento, vestidos de luto, prendas encontradas en el Salón Muare mezcladas con ropas a la venta en diferentes locales.

La revista recurre en muchas ocasiones a las prendas o accesorios del Salón Muare que es un lugar de alquiler de piezas clasificadas prolijamente por épocas y estilos. Lo significativo de esta operación es que las piezas del Salón no están a la venta ni son alquiladas por particulares sino que es un lugar destinado a abastecer producciones publicitarias, cinematográficas o artísticas.

La primera fotografía nos muestra a dos niñas similares a las trabajadas por Diane Arbus, ya que si no son gemelas parecen serlo, vestidas con ropa antigua y conventual que parecen recién salidas de una pesadilla. Son la versión en blanco y negro y más perturbadora aún de las gemelas que recorrían los pasillos de la película El Resplandor del director Stanley Kubrick, las niñas posaran separadas en otras dos fotos en las que se acentúa su carácter distante.

Las otras cuatro fotos son de un niño que genera una sensación igual de perturbadora. Dos de las fotos del niño nos lo muestran prolijamente vestido pero con sus ojos cerrados como si fuera la foto de un niño muerto, género tan apreciado hasta principios del siglo XX.

Sobre la relación entre la muerte y lo ominoso Freud nos dice: A muchos seres humanos les parece ominoso en grado supremo lo que se relaciona de manera íntima con la muerte, con cadáveres y con el retorno de los muertos, con espíritus y aparecidos... En verdad habríamos debido empezar nuestra indagación por este ejemplo, quizás el más rotundo, de lo ominoso, pero no lo hicimos porque aquí lo ominoso está demasiado contaminado con lo espeluznante... (2009, p. 241) Freud señala que el vivo mantiene el vínculo con el muerto en el amplio comercio con los espíritus, la relación es angustiante ya que "...el muerto ha devenido enemigo del sobreviviente y pretende llevárselo consigo para que lo acompañe en su nueva existencia”. (p. 242) Según Freud la represión de este pensamiento primitivo sucede en las personas cultas que ya no creen en las diversas manifestaciones de ánimas y espíritus. Si bien podemos reprimir o racionalizar nuestra relación con la muerte y el terror que produce el contacto con lo muerto el arte (especialmente el cine y la literatura) han sabido aprovechar esos temas en un millar de películas que se inscriben el género de terror.

George Bataille elabora también el tema de la muerte y la vinculación de los vivos con el cuerpo muerto. Más allá de la repulsión natural que significa ser testigos de la corrupción de la materia, más allá de los temores que generan el contagio y las pestes provocadas por la descomposición de la carne, el vivo siente el rechazo y el temor de que en el cadáver queden los rastros de la violencia que arrasó con la vida. Es el paso del orden al caos La muerte era un signo de violencia, de una violencia que se introducía en un mundo que podía ser 
arruinado por ella. Aún inmóvil, el muerto formaba parte de la violencia que había caído sobre él; y lo que resultaba en el ámbito de lo que podía resultar "contagiado" estaba amenazado por la misma ruina a la que el muerto había sucumbido. (1997, p. 50) La literatura y el cine han abrevado copiosamente de esta imagen del cuerpo muerto como un cuerpo capaz del mal, que regresa o se queda en el mundo por venganza o por maldad y son infinitos los relatos que asocian la violencia con la que aconteció la muerte con la violencia que puede ejercer el cuerpo una vez muerto.

En el caso particular de la producción de la revista las fotos nos vinculan con lo ominoso en dos niveles diferentes, en primer lugar al mostrarnos a estos seres que parecen haber regresado de la muerte y en segundo lugar porque son niños vestidos y actuando de forma que no los representa como tales. Los dos aspectos de lo siniestro se construyen por determinados elementos formales, como son la utilización del blanco y negro, el uso del vestuario, pero sobre todo por el uso del cuerpo de esos niños en la construcción de la pose.

¿Cómo debe posar un niño para parecer un muerto? Cada una de las fotos si no puede mostrar la muerte en si misma nos señala la ausencia de vida. Ninguno de esos niños actúa como tal, no juegan, no se ríen, no se enojan, ni encaprichan, no se mueven, no son niños y como lo parecen solo queda pensar que estén muertos. El maquillaje y los ojos cerrados y las bocas entreabiertas de algunas de las tomas completan la ilusión.

La siguiente producción con niños se titula Infancia Imaginada con fotos y estilismo de Florence Arguello, son siete fotos en las que nos enfrentamos a niños castigados en un rincón mirando contra la pared, niños enfrentando directamente a la cámara con ojos desorbitados, niños con expresión de susto, con la mirada perdida y una apatía distante o enojados. En esta producción los niños son activos y no dudamos en considerarlos vivos aunque todo lo que sucede nos resulte extraño. En este caso se puede ver claramente la diferencia con la producción anterior. Estas fotos no nos remiten a lo siniestro, ni a lo terrorífico, ni a lo espeluznante. El sentimiento que elaboran gira alrededor de la angustia.

En todas estas producciones fotográficas rastreamos una profunda relación con las distintas definiciones que Freud encuentra acerca de lo siniestro, su relación con el automatismo, el lugar que ocupan los ojos en la comprensión del complejo de castración, la relación con las figura del doble, con lo deforme, con el cuerpo muerto, etc. Las producciones trabajan con una cantidad limitada de elementos, no hay escenografías ostentosas como en las producciones de la revista Vogue, en este caso la mayoría de las modelos posa contra fondos de colores neutros y no hay casi elementos alrededor de los cuerpos, es por esto que no es disparatado decir que la construcción de sentido funciona por medio de la pose. La pose construye el cuerpo ominoso y la estrategia aplicada es desvincularlo lo más posible del cuerpo real y latente.

La pose usada en todas las producciones analizadas remite el cuerpo de la modelo a un cuerpo objeto utilizando las mismas poses que una muñeca o maniquí o al cuerpo muerto separándolo de las pulsiones y sentimientos de la vida cotidiana.

El cuerpo en su relación con el dolor

En las producciones fotográficas de la revista Catalogue, así como en la mayoría de las revistas de moda y belleza y en la publicidad de todo tipo de productos, se somete al cuerpo femenino sistemáticamente a la 
representación del dolor físico. Este vínculo que se establece entre el cuerpo y su dolor al ser tan extendido merece un análisis.

Grupos feministas y colectivos de artistas interpretan que todo lo que sucede dentro de las páginas de una revista de moda y belleza implica necesariamente una violencia sobre el cuerpo y sobre el mismo ser femenino o sobre la condición de ser mujer. El Colectiva Mujeres Públicas es un grupo de mujeres que comenzó desde el año 2003 a realizar intervenciones artísticas, performances e instalaciones. Firman sus obras con el nombre del grupo y ninguna de ellas se identifica de manera individual, son un grupo y mantienen de ese modo el concepto de arte colectivo.

Dos trabajos del Colectiva son interesantes de ser analizados ya que elaboran la relación del cuerpo femenino con los condicionamientos sociales que le imponen el mundo de la moda y la belleza: El primero es la acción Esa belleza... que se desarrolló durante los años 2003 y 2004 en la cual el Colectiva intervenía afiches y carteles publicitarios instalados en la vía pública pintando sobre ellos con stencil las siguientes frases: "Esta belleza... mata", “Esta belleza... lastima”, "discrimina”, "miente”, "enferma”, "duele”, "oprime”, "cosifica”, "condiciona", "subestima”, "reprime", "controla", "castiga”, "deforma". Estas intervenciones ponen en evidencia cómo los productos de la industria de la moda y la belleza condicionan a la mujer, a su cuerpo y su relación con el entorno social. Esta instalación piensa sobre cuál es el uso que la publicidad hace del cuerpo femenino y cuál es el estereotipo que se muestra como condición de exclusividad, generando por repetición una imagen única de cuerpo posible que no se relaciona con el cuerpo de la mujer real que mira la imagen.

La segunda obra es la instalación del Museo de la Tortura que se organizó y montó como un espacio de exhibición de todos aquellos productos, objetos y requerimientos que al estar asociados al canon de belleza imperante en la modernidad son consumidos por las mujeres. De por sí la catalogación del espacio de exhibición con el nombre de "Museo" nos remite a una institución que históricamente ha generado un vínculo jerárquico y que condiciona las obras que cobija. En este Museo se reúnen objetos cotidianos del "mundo femenino", todos los que sirven para la presentación pública de la mujer, son los elementos, instrumentos y accesorios que usamos para arreglarnos y emerger del ámbito privado al público. Encontramos bucleras, planchitas, rizadores de pestañas, maquillaje, tinturas, pinturas, pinzas de depilar, pinzas para el cabello, cera depilatoria, máquinas depilatorias, tampones, instructivos para dietas y ejercicios, pastillas adelgazantes, etc.

La voz del Colectiva nos ayuda a comprender la obra cuando nos explica que: Es en el texto que acompaña a cada objeto donde se hace visible la tortura. Maquinarias rosadas que en casa parecían inofensivas, develan aquí sus fines últimos, reales: subyace detrás de cada aparato expuesto un fin normalizador.

Quizá, lo más llamativo de este museo es que en él no encontramos instrumentos extraños, de aspecto medieval, sino cosas que llevamos en la cartera o tenemos en el baño.

El Museo de la Tortura genera un mensaje contundente. La institución museo cobija obras que por el hecho de estar en ese espacio son consideradas inmediatamente obras de arte (la gran crítica de las vanguardias), en este caso el Museo de la Tortura nos predispone como espectadores a encontrar allí piezas de alto contenido negativo y todo lo que está en ese ámbito a partir de ese momento será visto como una agresión y violencia al cuerpo femenino. 
En este sentido el Museo de la Tortura tiene un carácter fundacional ya que crea una situación de malestar con respecto a aquellas cosas que por ser muy cotidianas pasaban desapercibidas a la crítica y eran usadas sin reparos o se podían llegar a considerar como piezas vinculadas a la liberación femenina como por ejemplo los tampones. Dos de los artículos que nos llaman la atención son las minifaldas y los tampones, objetos siempre relacionados con la liberación de la mujer en la década del `60 son vistos por el Colectiva como elementos que ejercen violencia sobre el cuerpo femenino.

La explicación radica en que si bien la minifalda fue la culminación de la liberación de las ropas pesadas que imposibilitaban el movimiento también limitan el movimiento de quien las porta obligándolas a ser cuidadosas en cada uno de sus gestos, limitando el paso, y el modo de sentarse y pararse, en la posibilidad de desenvolverse e interactuar con el mundo. Los tampones parecen estar tan vinculados con la liberación femenina como la píldora y el Colectiva nos señala que el algodón de que están hechos esta blanqueado con productos cancerígenos lo que responde a la propia incapacidad de la sociedad de asumir naturalmente que la mujer menstrua y transforman la necesidad de ocultar ese hecho natural aunque sea con riesgos para la salud.

La antropóloga Bárbara Guerschman comenta en la revista Myriades 1 que "la moda era una forma de tortura legalizada" (2007, p. 20). El vestido, el peinado, el maquillaje, los gestos y movimientos que las sociedades de cada época imponen en la mujer son ritos lo suficientemente complejos como para ocupar tiempo, energía, dinero y dedicación en tal magnitud que inhabilitan las posibilidades de desarrollo de otros ámbitos.

Tradicionalmente la mujer se ha vestido y arreglado para exhibir y poner de manifiesto el status social y económico de su familia o marido. Es por esto que la mujer porta las joyas y los vestidos más llamativos y es el exhibidor de los logros familiares. Marcelo Marino nos cuenta que históricamente el vestido femenino era una carga que inmovilizaba a la mujer con un peso que podía exceder los $10 \mathrm{kilos}$, dependiendo de la época. Llevarlo demostraba dos cosas fundamentales: en primer lugar que la mujer tenía a su disposición los ayudantes necesarios para asistirla en la colocación de las prendas y en segundo lugar que esa mujer no necesitaba moverse en todo el día y por consiguiente no necesitaba trabajar ni fuera ni dentro de su casa. Dos elementos que demuestran claramente el status social de pertenencia.

Es por esto que tanto el vestuario, los productos de belleza y accesorios como todas sus maneras de difusión, exhibición y comunicación son vistos como un sistema de control social que ejercen violencia contra la mujer. El caso de la Revista Catalogue establece una diferencia con el resto de las publicaciones femeninas ya que como vamos a analizar la relación con la violencia es mucho más clara y concreta y no hay ninguna intencionalidad de usar metáforas.

La segunda y la tercera edición de la Revista que corresponden a la temporada Alto Verano y Colección Invierno del año 2007 abundan en producciones donde se elabora y banaliza la mortificación del cuerpo. Nos limitaremos a analizar las producciones de estos dos números ya que son lo suficientemente ricas y variadas como para permitirnos trabajar una idea acerca de cómo es el acercamiento al tema en la línea editorial de la revista.

En el Alto Verano de 2007. Número 2 de 2007

La primer producción que podemos analizar se titula Dolor y está compuesta por seis fotografías a página completa de Cecilia Glick con producción del Estudio Mangini y asistencia de Magdalena Freitas. El epígrafe 
dice lo siguiente: "El dolor, la suprema emoción de la que el hombre es capaz, es a la vez, el modelo y la prueba de todo gran arte". (p. 41) Difícil precisar que es lo que significa esta frase más allá de su contenido sonoro, suena interesante la unión en una oración de conceptos como dolor, emoción y "gran arte" pero no es posible encontrar una interpretación concreta.

Las fotos nos muestran a una modelo en la que se mezclan las expresiones de dolor y de simple fastidio mientras es colgada de arneses y sogas que marcan y estrangulan su cuerpo y la halan y tiran de una esquina a otra. Así como la imagen de un otro diferente aparece edulcorada y sin contenido la representación de la relación entre la violencia y dolor y el dolor y el placer también se diluyen y se estetizan tanto que pierden contenido. La modelo parece actuar algo similar al sufrimiento sin perder la línea estética que defiende la revista, sufre sin despeinarse y mientras la cuelgan mira desafiante y de manera sensual al espectador.

En el mismo número la siguiente producción que trabaja sobre la violencia es Warrior in Love que no registra créditos y está compuesta por tres fotos a página completa y dos fotografías a doble página. En la primera foto vemos a una mujer que cayó de la escalera y unos globos rojos se elevan sobre ella como si fueran el alma que abandona el cuerpo, ella queda sola y muerta en el suelo de un espacio que por su estructura y color nos remite a una fábrica. Otras mujeres cuelgan, otras se pelean, luchan, sufren todas ubicadas en la misma locación. (Ver Anexo $N^{\circ}$ 9) La visión de la mujer personificando a una guerrera en este caso está apoyada por la elección del lugar y por el estilismo. La acción sucede en una fábrica, lugar destinado en las producciones de moda a escenas de carácter urbano y futurista, la ropa se elige en colores rojo, negro y plateado, de látex y lycra, son prendas apretadas, calzados con tacos aguja de charol que refuerzan el sentido de la mujer guerrera herencia del comic y de los dibujos animados. La siguiente producción es Agua Salada con fotografía de Nacho Ricci, estilismo de Doiss Messeder y producción de Fer Furlone y Laura Scavo. En ocho fotos vemos a una modelo exhausta que transpira hasta desmayarse ejercitándose en una bicicleta fija. En su rostro captamos distintas expresiones que pasan desde el dolor que el esfuerzo le provoca hasta las muecas más agresivas que se usan para darse ánimo y lograr soportar la prueba física. El texto de la producción nos marca, "Nunca se debería confiar en una mujer que dice su verdadera edad. Una mujer que dice eso puede decirte cualquier cosa". Sin que podamos encontrar relación entre el texto y la imagen, volvemos a tener una frase sonora de connotaciones profundamente agresivas con respecto a una situación normal e insalvable en la vida de una mujer y de cualquier ser vivo que es el paso del tiempo y por consiguiente su edad. Las fotos son monocromas: contra fondo negro una modelo de cabello oscuro esta vestida en tonos blanco y negro, solo resalta el color violeta de sus labios expresando el dolor que la prueba física le produce. En todas las fotos el cuerpo de la modelo se nos presenta fragmentado, una boca que sufre, unas piernas que se esfuerzan, unos brazos agotados que caen, una espalda vencida, un cuerpo caído sobre la bicicleta fija, el cabello empapado sobre la cara que cubre el rostro y los brazos. Nada nos remite a una persona real sino a la teatralización de un sufrimiento por partes, profundamente estetizado.

La última de las producciones de este número que es interesante reseñar se llama Vedada con fotografías de Eleonora Margiotta, estilismo de Denise Massri y Dominique Rodrigué, asistencia de fotografía de Verónica Romanenghi y una poesía de Connie Ansaldi que se imprime sobre la última foto y dice: Bendito cruel que desarmas mis bordes.

Los huesos inertes que ya no visten sólo las manos tocan aquello que fue. 
Y en el calor de tu aliento, sola otra vez derretida.

Este poema que aparece al final de la producción más larga del número, que consta de once fotografías, se refiere a la cera depilatoria. Ese es el tema de la producción y por consiguiente vemos a la cera en sus contenedores habituales que podemos encontrar en cualquier lugar dedicado a la depilación y a una modelo vestida con encajes y tules que nos remite a una novia en el momento en que vestida se depila las axilas, la línea del cavado, pierna entera, bigote, etc. en todas las fotos la modelo nos oculta su rostro que aparece cubierto por tules, máscaras y velos y lo que podemos ver es a una joven en ropa interior o con solo la parte interna del vestido en la exhibición de un momento íntimo, de ahí el nombre de la producción: Vedada, son las fotos del momento que no vemos nunca, el momento de una preparación que no es pública para estar lista para un magnifico evento que si lo es.

Estas son las cuatro producciones que se trabajan en este número de la revista Catalogue, cada una elabora el tema de la violencia infligida en el cuerpo desde distintos puntos de vista y de diferentes maneras. En la primera el dolor es estético y se mueve al ritmo de un baile que provocan las cuerdas en el cuerpo de la modelo, en la segunda el dolor es la lucha y la pelea de dos mujeres que se enfrentan, en la tercer producción el dolor lo inflige la misma modelo sobre su cuerpo sometiéndolo a una rutina de ejercicios excesiva y por último el dolor lo produce la búsqueda de la aceptación del otro y deja constancia de lo que una mujer haría por agradar y satisfacer la mirada del otro: plantea que la mujer está dispuesta a rechazarse a sí misma y a su cuerpo sometiéndolo a rituales dolorosos que lo mortifican por acceder a la instancia del matrimonio, meta necesaria en la vida femenina. Es interesante analizar estas producciones a la luz de las investigaciones que Michel Foucault realiza sobre la problemática de la violencia y del poder y su relación con el cuerpo que la recibe y que la ejerce: Ha habido, en el curso de la edad clásica, todo un descubrimiento del cuerpo como objeto y blanco de poder. Podrían encontrarse fácilmente signos de esta gran atención dedicada entonces al cuerpo, al cuerpo que se manipula, al que se da forma, que se educa, que obedece, que responde, que se vuelve hábil o cuyas fuerzas se multiplican. (2004, p. 140) Entendemos que esta relación no es intencional pero es interesante analizar las locaciones de las producciones en función del análisis de Foucault de la distribución de la disciplina. El autor plantea en primer lugar que la disciplina exige clausura, clausura en el literal sentido del encierro o del perímetro delimitado, “...la especificación de un lugar heterogéneo a todos los demás y cerrado sobre sí mismo” (2004, p. 145), colegios, cuarteles, fabricas, hoy incluimos los barrios cerrados como el lugar marcado por la disciplina sutil, por otro lado la disciplina exige el establecimiento de un espacio que permita ser controlado, y este claramente asignado.

Las producciones eligen como espacio de ubicación la fábrica, el gimnasio, la camilla que nos remite al emplazamiento sanitario y la nada o el vacío. Estos son los espacios que habitan los cuerpos de las mujeres atravesadas por la violencia y el dolor, y son los espacios modernos de control y de sometimiento. El espacio del gimnasio se plantea como centro del control moderno hacia el cuerpo de hombres y mujeres. Michel Foucault nos dice que "...la única ceremonia que importa realmente es la del ejercicio" (2004, p. 141) esta es una disciplina de fuerte relación con la acción conventual. En ambos casos el cuerpo se somete a rutinas fijas muy estrictas, que pueden ser dolorosas o no pero que siempre incrementan paulatinamente el grado de dificultad. El cuerpo es tanto el obstáculo a vencer como el medio por el cual logramos nuestro objetivo.

El cuerpo se disciplina para que no sienta deseos o placer, ya sea por el sexo o por la comida. Foucault plantea que "Es dócil un cuerpo que puede ser sometido, que puede ser utilizado, que puede ser trasformado y 
perfeccionado". (2004, p. 140) Desde la época clásica el cuerpo ha sido el objeto de mortificación y de comparaciones insidiosas de las que no podía salir airoso, tratar de establecer una jerarquía entre el cuerpo y el alma desde la época griega relegó al cuerpo a un segundo plano en el que no era más que un mal necesario que debía ser sometido y controlado por medio del dolor. La religión católica recupero esta concepción dual del ser humano y estableció los rituales necesarios de dominación corporal. El cuerpo y sus pulsiones debían ser vencidos por medio del control y de la disciplina, y de este modo se estableció un catálogo de suplicios y mortificaciones, que incluían aparatos como los silicios, látigos y púas, y las acciones como los rezos, ayunos y abstenciones.

En sus investigaciones sobre el cuerpo femenino en relación al abordaje que se realiza en las revistas de fisicoculturismo Beatriz Ferrús plantea que, El cuerpo femenino pecador, pero también el modelo imposible de una madre-virgen, son los estigmas con los que cargan las mujeres de todas las épocas... Como "útero andante" o "lasciva tentación de Satanás", la mujer se convierte en la responsable del "pecado de la carne", en aquella que debe castigar doblemente su cuerpo, pues su falta es doble; al tiempo que, no debe olvidarse, los tratadistas y moralistas del medievo dudaron de la existencia del alma de las mujeres, por lo que la relevancia del cuerpo en la tradición femenina se va a ver incrementada. (2007, pp. 222-223) La modernidad modificó nuestra relación con el cuerpo pero no por eso lo liberó del dolor, el cuerpo de la mujer moderna se somete a rutinas interminables y dolorosas con el único fin de agradar a otro tan abstracto como inexistente para lo cual busca mutar y modificarse hasta acercarse lo más posible a una imagen construida por la visión de mil cuerpos diferentes. Este sometimiento del cuerpo a las exigencias de la moda se construye por medio de ejercicios, cirugías, tinturas, pigmentaciones, maquillajes, vestuarios, posiciones, etc.

El cuerpo es diseñado a voluntad y eso lo transforma en el protagonista, en el centro de todas las discusiones y del sistema económico y productivo. Nuevamente Beatriz Ferrús nos dice, Sin embargo, mientras las mujeres tratan de borrar su cuerpo por medio de la ascesis, la profesión conventual o diversas formas de control y punición, es tanto su esfuerzo de borrado, que terminan por subrayarlo, por convertirlo en el protagonista de su discurso, por encontrar en él el lenguaje del que son privadas en los discursos públicos. etc. (2007, p. 223) La producción Vedada de Eleonora Margiotta tuvo una continuación como serie dentro de la producción artística de la fotógrafa: Vedada 1. (Ver Anexo $\left.N^{0} 10\right)$ Esta continuación se compone de una serie de fotografías en las que retrata a personas comunes en un cubículo típico de cualquier centro depilatorio, donde hombres y mujeres recostados en camillas blancas se encuentran en ropa interior, casi indefensos frente a lo que en breves instantes va a suceder. Las palabras de la serie nos elaboran el sentido de las imágenes: "El objetivo de Eleonora con esta obra fue retratar con crudeza como estamos expuestos y somos despojados de toda vanidad en situaciones cotidianas. Todos hermanos en la fragilidad. E igualmente solos".

Este trabajo es totalmente diferente al de la producción de la Revista Catalogue. Si bien el tema es exactamente el mismo, los cuerpos son reales y muestran sus marcas reales, algunos delgados, otros más robustos, cuerpos jóvenes y viejos, obviamente con bellos, estrías, marcas del tiempo. En esos cuerpos el sentido de fragilidad es patente y pronunciado, comprendemos un sentido profundo y conmovedor del cuerpo que se expone indefenso a una práctica dolorosa que cree necesaria, el mismo entorno es siniestro: cubículos mínimos, asfixiantes, pulcramente asépticos.

El mismo concepto en otro cuerpo y en otro contexto cambia el sentido totalmente. Sucede aquí lo mismo que analiza Yolanda Domínguez con respecto al uso de la pose en la fotografía de moda, la pose y en este caso el 
concepto en otro contexto pierde sentido, pierde su verosímil.

En el Invierno de 2007. Número 3 de 2007

La Revista número 3 tiene sobre este tema dos producciones importantes de analizar. La primera es No te matarás, una idea de Jimena Nahón, Sol Abadi y Diego Speroni, Fotos de Sol Abadi y retoque digital de Diego Speroni. (Ver Anexo $\left.N^{0} 11\right)$ Son seis fotos en las que una modelo muere víctima del consumo de objetos de moda. El epígrafe dice: "No hay motivo que justifique hasta el último sacrificio, algunas mujeres no lo entienden".

En la primer foto una modelo muere cuando el taco aguja de su zapato se clava en su cuello del que brota una espesa sangre negra. En la segunda imagen la modelo muere aplastada por una cajonera y de su boca mana un hilo de sangre brillante y espesa, ella esta desnuda salvo por una diminuta bombacha y un collar que cubre su torso del que fueron borrados los pechos, a su lado una cartera. En la tercer imagen ella cae y rompe su cabeza contra un espejo, en la cuarta es aplastada por zapatos y carteras, luego la encontramos a punto de caer al subir a un mueble para tratar de encontrar un zapato perdido y por último muere asfixiada por una cartera.

En todas las fotos el fondo es un continuo blanco, no hay suelo ni paredes reconocibles, es el espacio de la nada. Por obra del retoque digital el cuerpo de la modelo se ha transformado en la textura de un maniquí o de una muñeca ya que no podemos percibir ninguna marca o imperfección.

De repente las mismas piezas que dan sentido a la existencia de la revista son culpables de crímenes atroces, el deseado zapato es el arma con el que la modelo se mata. Es una muerte profundamente estetizada y bella, ni la sangre parece sangre ni los golpes remiten al dolor, es la representación de la muerte por medio de la belleza.

Este vínculo entre la moda, la muerte y podríamos incluir la belleza, no es actual sino que viene de larga data. Siguiendo los pasos de Giacomo Leopardi podemos relacionar a la moda con la muerte, por el carácter efímero que la constituye y por su vinculación agresiva con el cuerpo. En 1824 escribe sus Poemas Morales en los que relaciona a la moda con su hermana Madame Morte: Yo persuado y obligo a todos los hombres gentiles a soportar cada día mil esfuerzos e incomodidades y a menudo dolores y sufrimientos; y a alguno a morir gloriosamente por el amor que me profesa.

Yo me conformo generalmente con la barba, el cabello, los vestidos... y no me privo de realizar numerosos juegos comparables a los tuyos, corno verbigracia perforar orejas, labios o narices y dañarlos con las naderías que cuelgo de sus orificios, abrasar las carnes de los hombres a los que obliga a practicarse tatuajes por motivos de belleza, deformar las cabezas de los niños con vendajes y otros ingenios... deformar a la gente con calzados demasiado estrechos, dejarlos sin respiración y hacer que los ojos se les salten por la estrechez de los corsés y cien cosas más de esta naturaleza.

La moda persuade y si no convence obliga y siempre somete porque todos sabemos que es el parámetro con el que el otro (sea real o ilusorio) va a juzgarnos. El uso de una violencia explícita en el marco de una producción de moda no puede dejar de sorprendernos. Es la manera de poner en evidencia lo que en otras revistas suele ser matizado, como son las dietas, ejercicios y ropas que mortifican el cuerpo y se presentan por medio del eufemismo y de la exaltación rodeada de adjetivos pomposos. 
La producción El Fin..., lleva lo antes mencionado hasta el extremo más dramático. La producción fue realizada y concebida por los fotógrafos Gabriel Machado, José Cicala y el director de arte Fabián Morassut, quienes acostumbrar trabajar juntos en su estudio desde 1995.

Son tres fotografías, en la primera a doble página vemos a dos modelos en ropa interior con su cuerpo ensangrentado, una rubia de rodillas que sostiene a otra (morena) que está atada de manos y con los ojos vendados con una tela. La soga roja que ata las manos de la modelo caída se enrosca alrededor del cuerpo de la modelo arrodillada que tiene sus pechos desnudos, confundiendo así la identificación de víctima y victimaria. Los gestos son la representación edulcorada de un gesto duro y violento, la representación diluida de la crueldad.

Como es común en las producciones de la revista la escena transcurre en un lugar neutro, todo sucede en un infinito gris en donde confundimos el suelo con las paredes, lo cercano con lo lejano, no hay línea de horizonte ni ninguna referencia espacial. Las modelos se mueven y luchan sobre un polvo blanco, similar a la tiza, que ensucia sus cuerpos y se mezcla con la sangre.

La siguiente foto nos muestra a la modelo morena con su cara descubierta y vemos como unas manos le atan dos vueltas de alambre de púas alrededor de la boca, cortándole la piel. La víctima sufre sin expresar dolor. Las manos que sostienen y tensan el alambre están cubiertas de sangre y las muñecas están vendadas con gasas blancas también manchadas. La tercera foto nos muestra a la modelo rubia atada, desnuda con el cuerpo sucio de tiza blanca, los brazos atados a la espalda por una tela roja y en su cintura una soga también roja. Parece ser una interpretación de la Venus restaurada de Man Ray, un maniquí atado con sogas. Pero el cuerpo de la modelo y el juego al que se someten las dos juntas dista mucho del efecto que provoca la misma soga en un maniquí plástico.

El texto de la producción dice: "Creemos saber cómo queremos vernos, cómo queremos que nos vean, pero no nos preparamos para un camino irreversible. En la búsqueda del modelo de belleza perdemos nuestra autenticidad".

La mortificación al cuerpo que reciben estas modelos por medio de la frase se vincula a la mortificación de la que es víctima el cuerpo para agradar y por someterse a los dictados de la moda y la industria de la belleza. Si bien la censura parece ser fuerte, la belleza de los cuerpos, lo cuidado de la pose y la asepsia del trabajo diluye el sentido crítico de la producción.

Esa intención de agradar y agradarnos adquiere un sentido de profunda búsqueda por medio del dolor. Tal como escribió Sade y teorizó posteriormente George Bataille, los vínculos entre el dolor, el erotismo y la muerte son estrechos: "El terreno del erotismo es esencialmente el terreno de la violencia, de la violación”. (1997, p. 21.) Bataille va más allá cuando expone "...que el impulso del amor, llevado hasta el extremo, es un impulso de muerte" (1997, p. 21). Los surrealistas como Dalí y Man Ray elaboraron sus reflexiones en torno al orgasmo "una pequeña muerte" el momento en el que el cuerpo se abandona y se deja de ser quien se es para morir por un instante.

Dos mujeres desnudas y atadas, manchadas de sangre remiten a esta categoría de erotismo que Bataille trabaja. En su libro la Historia del ojo (1997) la descripción de una de las primeras escenas de sexo en la que 
participan los protagonistas nos representa la siguiente situación: Yo estaba pálido, manchado de sangre, vestido de cualquier manera. Cuerpos sucios y desnudos yacían detrás de mí en un delirante desorden. Trozos de cristal habían cortado y hecho sangrar a dos de nosotros; una joven vomitaba; se habían apoderado de nosotros ataques de risa tan violentos que unos habían mojado sus ropas y otros su sillón o el suelo; se desprendía un olor a sangre, a esperma, a orina y a vómito que hacía retroceder de horror. (1997, p. 61-62) En Bataille el erotismo está marcado por el horror, ya que el erotismo es la transgresión del límite socialmente impuesto, es “... la aprobación de la vida hasta en la muerte”. (1993, p. 15) La producción Doloroso Placer de la Revista número 5 del 2008 trabaja desde el tema del sadomasoquismo, con todos los elementos que nos permiten identificarlo de manera precisa e inmediata. Dos modelos se juntan, se desean, se alejan, visten de cuero o de sintético brillante, la ropa es apretada, usan zapatos de taco aguja y tienen los senos descubiertos. Las poses buscan las formas más claras de remitir al imaginario colectivo de gestos sádicos: una le pega a la otra con el látigo, la pisa con un taco aguja de metal o la ata con cadenas. (Ver Anexo № 12) Las referencias no buscan ser sutiles sino inmediatas y en la elección de la pose y del vestuario prima que el espectador interprete el mensaje con claridad pero también buscan sostener un ideal de belleza que no se ha perdido en ninguna producción por más que el tema elegido sea la mortificación directa del cuerpo, su vejación y su objetivación.

Siguiendo el análisis de Bataille podemos afirmar que si el erotismo es el triunfo del ser humano sobre la condición animal, y por consiguiente siempre implica una sofisticación y una exacerbación de lo sexual (lo sexual que no es más que la necesidad reproductiva que tenemos como especie), entonces necesariamente el sadomasoquismo es parte del erotismo y de ahí su relación con el dolor, el sufrimiento y la muerte. La presencia de la muerte como posibilidad está presente en el sadomasoquismo. Aunque en la realidad de los hechos los individuos ni siquiera la rocen, el coqueteo con la muerte es necesario.

Los abordajes de las producciones son diferentes, lo significativo es la recurrencia con la que se utiliza el cuerpo doliente para la estimulación del deseo. Ya que la moda es eso, es deseo de poder, deseo de ser, deseo de parecer para uno y para otro.

Una antigua construcción social nos condicionó a pensar que cuanto más doloroso el proceso más eficiente y deseable es el resultado. Si la moda duele al portarla o al prepararnos para ella es porque realmente será más satisfactorio el resultado final, es por esto que nos subimos a un taco de $15 \mathrm{~cm}$ que deforma nuestra espalda, se usan corset tan apretados que impiden la respiración, se alisa el cabello con productos cancerígenos, se realizan dietas tan bajas en calorías que se produce daño físico y psicológico o nos sometemos a ejercicios que atentan con nuestra fortaleza cardiaca. Tendemos a creer que cuando más doloroso y difícil es el esfuerzo más felicidad nos espera al final del camino.

La constatación nunca sucede ya que luego de alcanzar el objetivo debemos someternos a la no menos penosa tarea del mantenimiento de lo alcanzado, por lo tanto el esfuerzo se sostiene infinitamente y podemos evitar el momento de evaluación del resultado.

En el caso de estas producciones ninguna sostiene un sentido crítico real, ni en los textos ni en las imágenes, no se está problematizando la relación entre la moda y sus requerimientos al cuerpo ya que cuando el dolor se mezcla con la belleza lo que prima es la belleza.

El cuerpo en su relación con la belleza. Perlas. Lo inasible del cuerpo bello 
Perlas se titula la producción de la Revista Catalogue número 3 del año 2007 para la colección Invierno. Con fotografía de Sol Abadi, estilismo de Florencia Arguello y retoque digital de Diego Speroni. Son cinco fotografías más la foto que fue utilizada para la portada de la edición. (Ver Anexo № 8) En la primera foto de la producción vemos como una modelo lujosamente ataviada en un vestido de piel (un saco de visón puesto al revés) se presenta en actitud frontal y tonos homogéneos. Su cabello ha sido reemplazado por ristras de perlas en color natural que se integran con el color de un sombrero de fieltro, del vestido, del rostro y de toda la piel maquillada, logrando un efecto monocromo que se acentúa con el fondo de color neutro. Un texto en letras negras nos señala, "Amalas, son un privilegio de la naturaleza". Refiriéndose a las perlas. La frase ejerce un fuerte contraste con la expresión y pose de la modelo quién nos demuestra una apatía rayana en el trastorno psicológico.

Las otras dos fotografías son de una misma modelo a quien la rigidez de la pose y las características de su cuerpo, extremadamente delgado y sin formas, transforman en un muñeco. La primera de estas dos fotos muestra a la modelo hasta las rodillas y la siguiente (la tercera de la producción) muestra solo su rostro. La cuarta y quinta foto funcionan de manera equivalente pero con otra modelo, la primera nos muestra a una joven con un vestido corto y un collar de perlas de mil vueltas y la siguiente nos muestra solo su rostro en un plano muy corto.

Todas las fotos son igualmente monocromas y utilizan un fondo neutro.

Las perlas, el tema de la producción, el eje que determina el color y los modos de representación de las figuras son justamente lo que no está en venta. Son perlas, no collares que puedan encontrarse en una tienda. Como el título lo indica son un privilegio de la naturaleza al que no es fácil acceder y en el marco de un catálogo que dirige las compras del usuario, esta compra especialmente está vedada.

En la foto de la tapa la perfección del rostro de la modelo la iguala a un dibujo, con las pestañas finamente delineadas, los rasgos delicadamente marcados, un color artificial. No hay marcas, lunares, poros, la exageración del retoque digital nos hace imposible identificar una persona detrás de esas fotos, solo vemos una bella y perfecta muñeca, disfrazada para ser más bella aún.

En todas estas producciones las imágenes están fuertemente retocadas y digitalizadas, maquilladas y arregladas, acomodadas para parecer otra cosa que lo que realmente son. Se da la operación contraria a la del cuento de Hoffmann, en el que una autómata construida simula ser una mujer real, en estos casos las mujeres reales pretenden ser muñecas y automatizan sus gestos y poses para lograrlo.

El resultado por ser inverso no es menos perturbador que en el cuento. Al ver una producción detrás de la otra y ver la repetición sistemática que tiende a cosificar a las figuras femeninas construimos un concepto de mujer degradado. Lo que estas imágenes nos escatiman es la vida de esos cuerpos, sus pulsiones. Y la vida es lo que en la imagen, fotográfica o pictó- rica, identificamos como la individualidad, es lo que nos permite reconocer y desear al otro. Estas imágenes no buscan ese reconocimiento sino que nos indican claramente que ninguna de esas modelos que ha prestado su imagen es importante, son seres anónimos de los que casi nunca encontramos el nombre registrado en la revista y de las que no podemos rastrear seña alguna, probablemente si las encontráramos en la calle y las viéramos personalmente no las reconoceríamos. 
Tampoco buscan o conducen al erotismo o a la sensualidad. Son cuerpos distantes, fríos y rígidos que no dan señal alguna de vitalidad. En el siglo XVIII, durante el academicismo, se establecieron las reglas que debía seguir el desnudo artístico, haciendo un análisis sobre los modos de representación social del cuerpo y sus implicaciones.

Al definir las normativas del desnudo la Academia lo hace teniendo en cuenta que la representación debe sublimar el cuerpo y no representarlo en su materialidad, como una forma de idealizarlo. Abigail Solomon Godeau expone cuál es la visión que Quatremére de Quincy plantea para establecer qué ideal debe seguir la representación del desnudo: Las formas serán modeladas con amplitud, simplificadas, purificadas, depuradas de cualquier detalle individual, de cualquier defectuosidad accidental. Las proporciones y las relaciones de las partes se fijaran con todo el rigor de una construcción matemática”. "[...] evitará a toda costa intentar, con el vano pretexto de animar sus figuras, imprimirle los caracteres que en la realidad denotan vida: la flexibilidad de la carne, la transpiración de la piel, la elasticidad de los músculos. Evitará que se adivine lo que se halla bajo el envoltorio exterior, el afloramiento de la estructura ósea, los músculos y las venas, ya que todo ello no es más que detalle 'animal'. (2004, p. 107) De Quincy, crítico de arte e ideólogo de muchos de los preceptos de la Academia de Bellas Artes de Francia en el siglo XVIII, nos ilustra todo lo que no debe ser mostrado, con el fin de plantearnos cómo es que se debe representar la imagen de un cuerpo desnudo, la definición trabaja por exclusión ya que la negativa es representativa de la conformación de un modelo que se caracteriza por ocultar o tapar, disimular lo que es propio del cuerpo en si para representar lo que en realidad sería propio de una idea o concepto.

En primer lugar está tratando de separar la llamada representación artística del desnudo, de la imagen que se considera o se usa de manera pornográfica, y que por consiguiente podría atentar contra los valores éticos, religiosos y morales de la época. La diferencia entre los diferentes fines que puede tener una misma imagen se centra en su capacidad de evocación erótica y de incitación al deseo. La línea muchas veces es tenue.

Esta manipulación de la imagen se realizaba tradicionalmente en la pintura, ocultando los órganos sexuales y las marcas propias del cuerpo que lo transformaban en un objeto palpitante y tibio. Pero esta operación no siempre fue fácil de trasladar a la fotografía, ya que la foto atenta contra el ideal remitiéndonos directamente a un modelo real, de existencia real, en un tiempo real. Esto quiere decir que la foto de una mujer desnuda implica inmediatamente la existencia de esa mujer desnuda, que por más que esté velada por tules y efectos especiales, estuvo desnuda frente al fotógrafo.

El cuerpo privado de todos los rasgos y atributos de su vitalidad (latidos, marcas, bellos, cicatrices, músculos, sudor, etc.) es un cuerpo privado de sí mismo y transformado en otra cosa, en un cuerpo títere que se presta al espectáculo, al show del diseño contemporáneo donde los protagonistas son otros.

En la representación de este cuerpo lo que se extrae es su necesidad, todo cuerpo tiene necesidades que se vinculan con lo fisiológico, con rutinas que son necesarias y obligatorias (comer, dormir, respirar, defecar, pestañear, etc.). De esta pesada carga de la necesidad nos libera el arte, el cuerpo que no está limitado por el temor de lo inmediato es eterno.

Bataille relaciona este tratamiento de la representación del cuerpo con una búsqueda de separar el cuerpo humano del cuerpo animal: La aversión de lo que, en un ser humano, recuerda la forma animal, es cierta. En 
particular, el aspecto del antropoide es odioso. El valor erótico de las formas femeninas está vinculado, me parece, a la disposición de esa pesadez natural que recuerda el uso material de los miembros y la necesidad de una osamenta; cuanto más irreales son las formas, menos claramente están sujetas a la verdad animal, a la verdad fisiológica del cuerpo humano, y mejor responden a la imagen bastante extendida de la mujer deseable. (1997, p. 149) La producción Enorme Belleza del número 5 de 2008 para la temporada de Verano, tiene fotos de Sol Abadi con asistencia de Meli Jenik y Jesica Trajtemberg, estilismo de Florence Arguello y asistencia de producción de Fátima Christie Newbery. (Ver Anexo $N^{\circ}$ 11) Son seis fotografías en las que la misma modelo posa de forma tal que no quedan dudas de que cumple con las condiciones y requisitos necesarios para ser considerada una mujer bella. Lo que llama la atención de la producción es la necesidad de remitir el cuerpo bello a un estereotipo clásico de mujer en la que nos encontramos a una niña / dama antigua que oscila (por sus ropas y estilismo) entre un retrato construido al modo de los dibujos infantiles de Sara Kay o de la mítica serie de La Familia Ingalls.

Encontramos en la revista la acción recurrente de vincular al canon de belleza características temporales pasadas en donde prima la delicadeza y la suavidad, mientras que la mujer moderna es representada como fuerte y violenta y su cuerpo pierde los atributos típicamente femeninos como son los pechos o las caderas marcadas.

El ideal de belleza es la construcción social que se realiza para definir qué es lo que este momento y este lugar van a considerar como bello, la pertinencia de esa elección como categoría dependerá del alcance de su difusión. Siempre y cuando todos hayamos comprendido e identifiquemos cual es el modelo elegido para representar lo bello eso será percibido como bello. Bataille nos plantea que "el margen de interpretación personal no es tan grande" (1997, p. 148). Nos gusta pensar que nuestras elecciones son nuestras y parte de un descubrimiento personal, pero la construcción de un ideal de belleza es un modelo social.

La construcción de belleza que el mundo de la moda y la publicidad han sostenido es la de la belleza ideal, no existe para este la belleza real, porque si es real ya no genera la misma fuerza de deseo.

El deseo se moviliza frente a lo inalcanzable. Los rituales a los que debe someterse el cuerpo para que la industria de la moda y la belleza sean viables económicamente son interminables, complejos, costosos y dolorosos y están diseñados para repetirse por siempre. Para que eso suceda, para que esto pueda funcionar el objetivo final debe encontrarse mucho más allá de lo posible. El ideal más fuerte que trabajan hoy la industria de la moda y la belleza es el de la juventud, solo se es bello mientras se es joven. Este principio es imposible de sostener para cualquier ser humano y es por esto que el cuerpo se somete a gran cantidad de procedimientos que son infinitos, como por ejemplo el uso de cremas, tinturas, cirugías, ejercicios, dietas, pastillas, inyecciones, injertos, etc.

Históricamente la construcción del canon se sostenía en el tiempo generando un concepto de larga duración al que podían remitirse varias generaciones. Hoy en día esto ha cambiado significativamente.

Martin Harrison recuerda a Sir Cecil Beaton quién en 1962 se sorprendía de esta cualidad temporal que empezaba a marcar inexorablemente los cambios en el paradigma de la belleza: "iQué imperceptible, pero rápidamente, cambia nuestra imagen de la belleza! ¡Hasta en dos años nuestro ideal puede dar un completo cambio!... Es un fenómeno curioso que la demanda de un nuevo tipo de belleza se vea siempre cubierta". (1997, 
p. 23) Sir Cecil Beaton se sorprende no solo del ritmo acelerado del cambio sino también de que siempre se encuentre quien lo encarne, siempre hay un cuerpo capaz de portar ese sentido. Distintos momentos han hecho convivir distintas interpretaciones acerca de qué es lo bello. Atravesamos un momento especial en el que no se busca establecer un modelo o canon general sino que se trabaja en nichos cada vez más pequeños, es por esto que hoy en día conviven múltiples concepciones de la moda, de lo bello y del cuerpo que representan a pequeños grupos y se dirigen y dialogan con estos.

Es evidente que las producciones de la revista Catalogue no abordan recurrentemente la búsqueda de un cuerpo bello o de la belleza en sí. O por lo menos no lo hacen de la misma manera que podemos percibir en las otras revistas de moda del mercado. En general la industria de la moda busca ser representada y presentada por la construcción momentánea de belleza imperante.

Pese a esto encontramos que las modelos conocidas no responden todas a los mismos descriptores, ya que encontramos modelos de cuerpos magros, casi masculinos o adolescentes, modelos voluptuosas, encontramos algunas rubias, otras morochas, más altas o más petizas y en todo un mundo de adjetivos perdemos la posibilidad de establecer un definición que incluya con coherencia a todos aquellos cuerpos que consideramos bellos. Más allá de esto podemos identificar a una modelo y asociarla, aunque sea vagamente, a la belleza. Esto se logra por repetición, estamos tan expuestos a las imágenes que produce la moda y la industria de la belleza que la familiaridad con esas personas específicamente nos permite construir un concepto mental, imposible de teorizar, acerca de la belleza.

Es por esto que la actualidad ubica con nombre y apellido a cada una de esas caras y esos cuerpos, a partir de los años noventa conocemos a las modelos que han devenido celebrities, nos son familiares sus imágenes y sus historias (que sirven para anclar el recuerdo). Las tradicionales revistas de moda y belleza como Vogue, Elle, Para Ti, etc. nos muestran a sus hijos, sus maridos, sus historias de vida.

Al reconocer esos cuerpos como los de las Modelos o Top models, los asociamos inmediatamente a la belleza, más allá de sus características especificas. La revista Catalogue no trabaja con modelos conocidas, ni con celebrities. Es por esto que nos cuesta reconocer en las producciones un concepto tradicional de belleza. En muchos casos las mujeres elegidas por la revista Catalogue escapan al estereotipo fácil que nos sirve como guía.

Hay en la elección de esas modelos un intento de transgresión y diferenciación. Las producciones de la Revista Catalogue no se organizan como en una tradicional revista de moda y se vinculan con el mundo del arte y de la fotografía contemporánea. Es por esto que en este estudio hemos relacionado las producciones con obras de artistas visuales contemporáneos y no con las producciones de otras revistas de moda, nacionales o internacionales.

El caso de la revista Vogue produce un resultado totalmente diferente. La Vogue ha trabajado históricamente con algunos de los mejores fotógrafos, pero las producciones que realizan para la revista siguen una línea editorial tan coherente que más allá de las diferencias estilísticas de cada artista, los resultados en cuanto al uso del cuerpo y a la elección de esos cuerpos es equivalente. Esto tiene su raíz en la elección de modelos profesionales conocidas popularmente. 
En las producciones fotográficas de la Revista Catalogue se elaboran problemáticas muy complejas que giran alrededor del uso del cuerpo femenino. El uso del cuerpo, la pose y su gesto son el elemento más pregnante que tenemos para analizar, ya que son elementos repetitivos y por eso importantes para entender de qué nos habla la Revista Catalogue cuándo nos habla de mujer, de moda y de belleza.

En muchas producciones el cuerpo es lo único que nos brinda la imagen, no tenemos escenografías costosas, ni locaciones, a veces no tenemos ni la ropa o accesorios que podemos adquirir y al trabajar con modelos desconocidas o con mujeres que no son modelos profesionales también nos priva de las historias que acompañan a la imagen de esos cuerpos. Cuando una consumidora de revistas de moda ve una producción personificada por una top model como Cindy Crawford, Valeria Mazza o Kate Moss el reconocimiento de esas figuras le permiten construir una narración y un sentido alrededor de la producción fotográfica. Los tres ejes que analizamos en este estudio giran alrededor del uso del cuerpo y su relación con lo ominoso, con el dolor y con la construcción de belleza. Llaman la atención por su repetición en muchas de las producciones, en muchos de los números y por sostenerse en el tiempo ya que podemos observar el tratamiento de estos temas hasta en la más reciente de las producciones de la revista aparecida para el verano 2013.

Dentro de este análisis el tema que encontramos de manera más recurrente es el uso del cuerpo en relación a lo artificial, a la máquina a la muñeca, a la construcción del cuerpo femenino como un cuerpo automatizado. Esto es importante porque el cuerpo es una construcción no es en si mismo.

Recuperando nuevamente la frase de Simone de Beauvoir, No se nace mujer: llega una a serlo. Ningún destino biológico, físico o económico define la figura que reviste en el seno de la sociedad la hembra humana; la civilización en conjunto es quien elabora ese producto intermedio entre el macho y el castrado al que se califica como femenino. Sólo la mediación de un ajeno puede constituir a un individuo en Otro. $(1987$, p. 13) Esa construcción de un ser como lo femenino se elabora a partir del cuerpo y de su pose social, o sea del modo en que se muestra públicamente y se exhibe frente al otro y esa construcción se basa en reproducirr ciertas tipologías que se establecen desde el mundo de la moda y la publicidad ya que se han colocado en el lugar de referentes. El cuerpo femenino como dice Le Breton no tiene que ver con su biología, ser mujer no se determina por un hecho fisiológico sino cultural que va a estar totalmente determinado por las imágenes a las que se enfrenta esa mujer. La imagen determina y construye un modo de ser mujer porque construye su cuerpo.

La revista Catalogue no tiene el mismo alcance y la misma difusión que otras revistas femeninas del mercado, pero apunta a mujeres que en muchos casos no consumen otras publicaciones. El modelo de mujer que construye la revista es el de una mujer fragmentada, con producciones que simulan una crítica al estereotipo femenino / masculino y a los condicionamientos de la moda, pero de hecho no se produce una crítica sino que se fortalece el estereotipo de mujer.

Refrenda el estereotipo de mujer niña, sumisa, dócil, y en cambio las mujeres fuertes son un tipo de mujer que renuncia a sus características femeninas, con cuerpos muy masculinizados, casi sin formas, con gestos muy violentos casi agresivos como si ser moderna necesariamente implicara la renuncia a ser mujer y la apropiación del rol asignado al hombre. Este estudio busca ser lo más interdisciplinario posible para que se permita pensar las producciones fotográficas como una situación problemática. Elaborar un tema como un problema nos permite 
partir de una pregunta lo que habilita el arribo a una respuesta para no limitarnos a un trabajo solamente descriptivo.

La pregunta que atraviesa esta investigación es cuál es el uso del cuerpo en la foto de moda, específicamente en la Revista Catalogue. Para poder comprender nos valimos del arte contemporáneo que funcionó como referente y como marco teórico. No hay duda de que esas problemáticas son las mismas que se trabajan, desde muchos abordajes diferentes, en el arte contemporáneo. Lo que sí nos llama la atención es el modo en que se trabaja, o los objetivos que podemos intuir, sostiene la revista en cada una de sus producciones.

La manera en que se muestra el cuerpo nos refleja un abordaje, una mirada en particular acerca de ese cuerpo que no es ajena de otras miradas posibles. Las construcciones que se hacen en torno a la marcación del cuerpo como lo ominoso no son necesariamente propias de la revista, sino todo lo contrario ya que pertenecen a un corpus de temas que se están manejando en el arte moderno y contemporáneo desde donde se piensan y problematizan. Ahí radica el interés de las producciones, ya que si bien son diferentes a otras producciones de moda no son diferentes a temas que conforman un interés contemporáneo. En el caso de la producción Vedada de Eleonora Margiotta, la artista trabaja como producción artística y también como producción de modas el mismo tema, en dos productos totalmente diferentes dando resultados diferentes. La producción de moda no profundiza en la problemática y se queda en un nivel puramente estético que no reviste mayor complejidad, en cambio la producción artística en la que utilizó la misma situación encarnada en otros cuerpos nos conmueve y moviliza profundamente. Esas son las producciones que resultan complejas de comprender ya que intuimos que pretendían hablar de algo que finalmente no se concreta, se esboza una crítica que finalmente no se produce.

Podemos aventurar una respuesta sobre por qué sucede esto, tiene que ver con la misma esencia de la revista que se fundamenta en el catálogo y que tiene las producciones como separadores de sus páginas, la revista tiene como esencia sostener el catálogo, la producción es el aporte estético y visual que la revista le regala a las lectoras.

Esta situación se debe a que la revista tiene identificado su público objetivo como un grupo de mujeres profesionales con sensibilidad por el arte y que no se moviliza por una revista de modas clásica, con horóscopos, notas, dietas y entrevistas.

Como plantea Jimena Nahón en la introducción del primer número, "Nos dirigimos a mujeres inteligentes". El estereotipo de mujer inteligente que maneja la revista separa a la lectora de las revistas femeninas tradicionales y las dirige a un nuevo formato de exhibición de los productos en donde se identifica claramente la intención de vender y la intención de disfrutar, el marketing y el arte.

Es por esto que la revista no contrata modelos conocidas, eso queda para la revista femenina, sino que concentra su interés en los fotógrafos. Todos los fotógrafos son conocidos en el medio, por sus producciones artísticas, de moda y belleza. La revista se transforma en un objeto de colección y se venden los contenedores acrílicos para guardarlas.

Pero por más que la revista trate de separarse del rubro de las revistas femeninas y elabore otros temas y con otras formas, el hecho de ser una revista de moda condiciona el abordaje de las producciones y por consiguiente determina su sentido. En sus hojas los temas se diluyen, se estetizan y se edulcoran. Así como las mujeres 
ubicadas en la vía pública por Yolanda Dominguez nos resultan ridículas por estar fuera de contexto, los temas elaborados por la revista nos resultan absurdos por que también los leemos fuera de contexto.

\section{Bibliografía}

Barthes, R. (1989). La cámara lúcida. España: Paidón. . (s.f.) Sistema de la Moda. Gustavo Gil S.A.

Bataille, G. (1993). La historia del ojo. España: Tusquets. . (1997). El erotismo. Madrid. Tusquets.

Bourdieu, P. (2002). Alta costura y alta cultura. En Sociología y cultura (pp. 215-224). México: Grijalbo, Conaculta.

Catalogue, $2007 \mathrm{~N}^{\mathrm{a}}$ 1, 2, 3, 4. Buenos Aires.

Catalogue $2008 \mathrm{~N}^{\mathrm{a}}$ 5, 6, 7 y 8 . Buenos Aires.

De Beauvoir, S. (1987). El segundo sexo. La experiencia vivida. Argentina: Siglo XX.

Ferrús, B., «Masculino y femenino en los tiempos del cyborg». En Meri Torras (ed.), Cuerpo e identidad I. Barcelona: Ediciones UAB, 2007. http://cositextualitat.uab.cat/web/wpcontent/uploads/2011/03/08.-Masculino-yfemenino-en-los-tiempos-del-cyborg.pdf Foucault, M. (2004). Vigilar y Castigar. Nacimiento de la prisión. Argentina: Siglo XXI editores.

Freud, S. (2009). Obras completas: De la historia de una neurosis infantil: El hombre de los lobos y otras obras: 1917-1919. 10 $0^{\mathrm{a}}$ reimp. V. 17. Buenos Aires: Amorrortu.

Harrison, M. (1987). Beauty Photography in Vogue. London: Octopus Books.

Hoffmann, E.T.A. (1993). Cuentos 1. España: Alianza Editorial.

Iglesias Saldaña, M. (2007). Genealogía de una historia. Historia de las mujeres, historia de Género:

Problemáticas y perspectivas. Espacio Regional, 2 (4), 121-126.

Le Breton, D. (2011). Sociología del cuerpo. Buenos Aires: Ediciones Nueva Visión.

Nazarieff, S. (1993). Early Erotic Photography. Alemania: Taschen Saltzman, A. (2009). El cuerpo diseñado. Sobre la forma en el proyecto de la vestimenta. Buenos Aires: Paidós.

Sánchez Moccero, M. (2007). Una moda que duele. Revista Myriades 1 (1, año 0).

Solomon-Godeau, A. Género, diferencia sexual y desnudo fotográfico. En: Picaudé, Valérie y Arboizar, Phillipe (2004). La confusión de los géneros en fotografía. Barcelona: Gustaban Gili S. A. 
Tarzibachi, E. (2010, 12 de febrero) ¿Qué pretende usted de mí? Página/12.

AA.VV. (2006). La belleza del siglo, Los cánones femeninos del siglo XX. Barcelona: Gustavo Gili Moda.

\section{Recursos Electrónicos}

http://www.revistag7.com/el-elegido/cuerpos-violentos/ recuperado 16 de nov. 2011 Páginas de artistas, fotógrafos y productores mencionados www.freakmodels.com.ar/ www.nicolacostantino.com.ar/ www.fabianabarreda.com/ www.vanessabeecroft.com

3.2. Los modos de representación del cuerpo en la fotografía de moda. Producciones fotográficas de la Revista Catalogue fue publicado de la página 284 a página319 en Cuadernos del Centro de Estudios de Diseño y Comunicación $\mathrm{N}^{\circ} 63$ 